\title{
Gendered Citizenship and Migrant Work in Canada
}

By Alexandra Law, B.A., LL.B., B.C.L.

A thesis submitted to the Faculty of Graduate Studies and Research in partial fulfillment of the requirements for the degree of Master of Arts

Department of Law, Carleton University

Ottawa, Ontario

March 30, 2007

C 2007, Alexandra Law 


$\begin{array}{ll}\begin{array}{l}\text { Library and } \\ \text { Archives Canada }\end{array} & \begin{array}{l}\text { Bibliothèque et } \\ \text { Archives Canada }\end{array} \\ \begin{array}{l}\text { Published Heritage } \\ \text { Branch }\end{array} & \begin{array}{l}\text { Direction du } \\ \text { Patrimoine de l'édition }\end{array} \\ \begin{array}{l}\text { 395 Wellington Street } \\ \text { Ottawa ON K1A ON4 } \\ \text { Canada }\end{array} & \begin{array}{l}\text { 395, rue Wellington } \\ \text { Ottawa ON K1A 0N4 } \\ \text { Canada }\end{array}\end{array}$

Yourfile Votre référence

ISBN: 978-0-494-26955-8

Ourfile Notre référence

ISBN: 978-0-494-26955-8

NOTICE:

The author has granted a nonexclusive license allowing Library and Archives Canada to reproduce, publish, archive, preserve, conserve, communicate to the public by telecommunication or on the Internet, loan, distribute and sell theses worldwide, for commercial or noncommercial purposes, in microform, paper, electronic and/or any other formats.

The author retains copyright ownership and moral rights in this thesis. Neither the thesis nor substantial extracts from it may be printed or otherwise reproduced without the author's permission.
AVIS:

L'auteur a accordé une licence non exclusive permettant à la Bibliothèque et Archives Canada de reproduire, publier, archiver, sauvegarder, conserver, transmettre au public par télécommunication ou par l'Internet, prêter, distribuer et vendre des thèses partout dans le monde, à des fins commerciales ou autres, sur support microforme, papier, électronique et/ou autres formats.

L'auteur conserve la propriété du droit d'auteur et des droits moraux qui protège cette thèse. $\mathrm{Ni}$ la thèse ni des extraits substantiels de celle-ci ne doivent être imprimés ou autrement reproduits sans son autorisation.
In compliance with the Canadian

Privacy Act some supporting forms may have been removed from this thesis.

While these forms may be included in the document page count, their removal does not represent any loss of content from the thesis.
Conformément à la loi canadienne sur la protection de la vie privée, quelques formulaires secondaires ont été enlevés de cette thèse.

Bien que ces formulaires aient inclus dans la pagination, il n'y aura aucun contenu manquant. 


\begin{abstract}
The Canadian Seasonal Agricultural Workers Program and the Live-In Caregiver Program facilitate migrant work in farming and home care, respectively. Though their industries differ, the programs are built upon similar assumptions about worker autonomy, transnational citizenship and the public-private distinction. This has consequences for migrating worker resistance in Canada. Workers first exercise transnational civil citizenship by signing an overseas contract. Conceived in law as autonomous contracting parties, they are nevertheless motivated by family relationships. In Canada, worker citizenship is managed through the work permit, a framework which enables workplace injustice. This injustice is maintained through a blurred line between 'just like family' and 'employee' status, and the public discourse of the 'family farm'. Using court cases as evidence, I conclude that worker disruption of the artificial line between public and private may result in positive legal change, including concrete gains in pay, benefits and labour protections.
\end{abstract}




\section{Acknowledgments}

I wish to thank my thesis advisor, Professor Rosemary Warskett for her attentive reading, her well-tuned advice and her support throughout the writing process. I am grateful to Rosemary for introducing me to a new set of literature and debates, and for helping me understand and clarify the significance of gender for migration, work and citizenship in Canada.

I would also like to express my appreciation to the thesis examination committee: Professors Diana Majury and Lisa Mills for taking the time to read and offer their helpful comments on the thesis, and Professor Peter Swan, for chairing the committee.

Thanks to Mr. Andrew Squires for sharing his institutional knowledge throughout the program, and for his advice on the administrative aspects of the thesis.

I am grateful for the friendship of my fellow Montreal expats, Anna Purkey and Michael Rowland, as well as the encouragement and stimulating debates of the 'Usual Suspects' in the Law graduate lounge. Thanks especially to Rajiv Prasad for challenging conversations and for many film and book loans.

Had I not met two people in particular, I would never have written the present thesis. I wish to thank Ms. Tess Tessalona of the Immigrant Workers Centre for her trust in taking me on as an intern four years ago. Tess leads by the example of her activism, to which she brings both a sense of humour and great integrity. Professor Roderick Macdonald has been my teacher, employer, co-author and mentor, often all at the same time. I am grateful for his encouragement and advice.

My family has been a constant source of love and courage. Thank you to my parents Julika Winkler and Stephen Law, my brother Adrian Law, to Ganny, Tante 
Deara, Dominique and Camille. Finally, to the late Helmut and Ruth Winkler, who made a home for all of us. 
Table of Contents

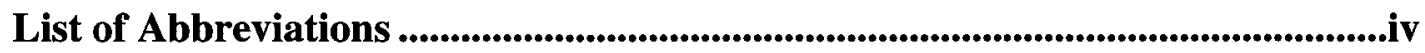

1-Contract, Migration and Citizenship: Farming and Caregiving Work in Canada

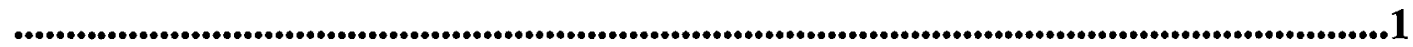

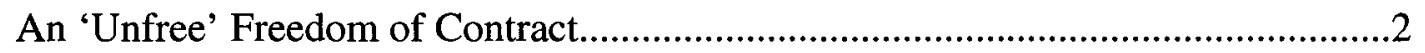

Theorizing Migrant Work: Transnational Citizenship...........................................6

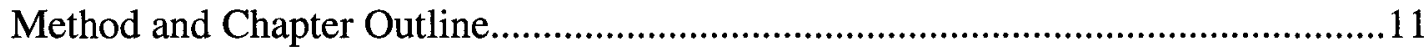

2-Origins: the Economic Migration Cycle and Canadian Labour Shortages....16

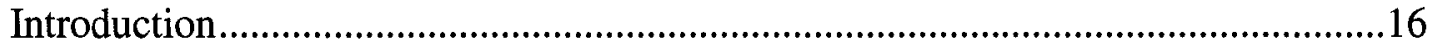

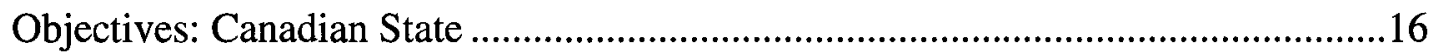

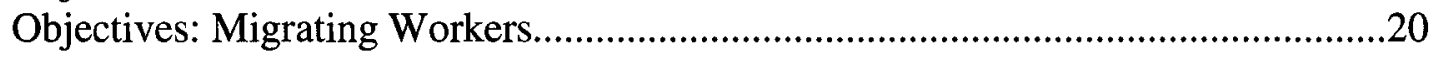

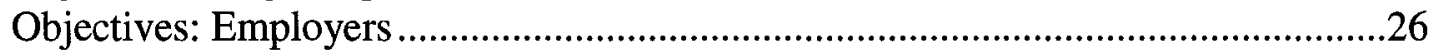

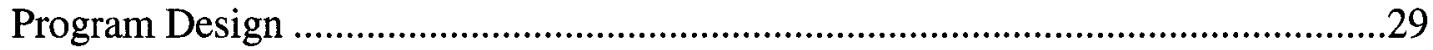

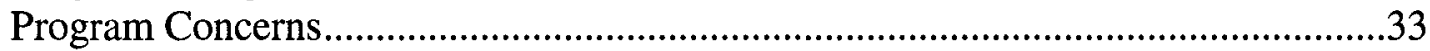

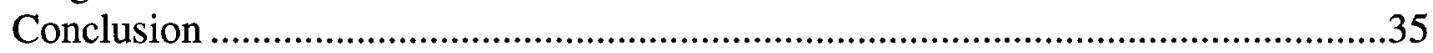

3-Transnational Citizens, Interdependency and the Public-Private Divide........37

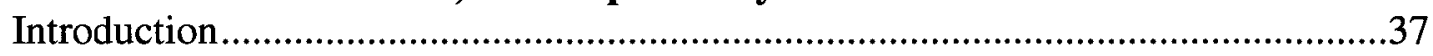

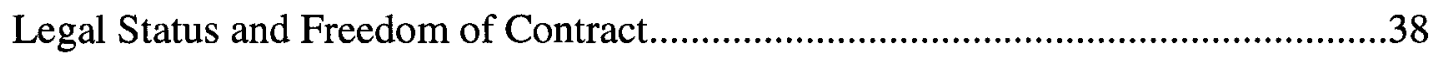

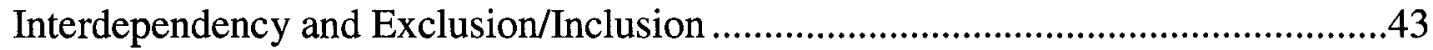

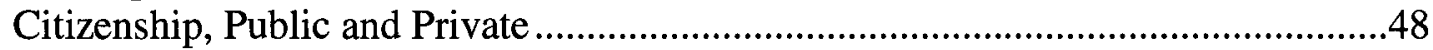

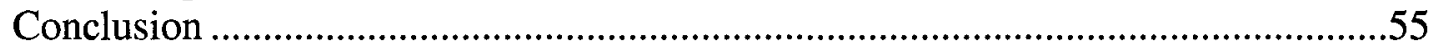

4-Gendered Citizenship, Worker Resistance and Legal Change ..........................57

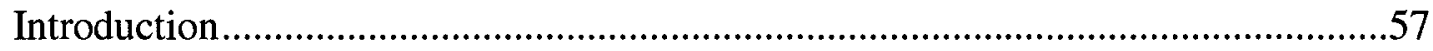

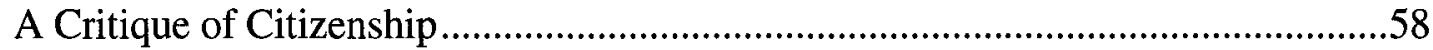

Interdependency, Recognition and Citizenship: Fraser v. Canada (2005) ...............60

Mirror Image: The Family Wage and Live-In Caregiving .....................................66

The Family Home, the 'Family Farm': Dunmore (2001) and its Aftermath .............68

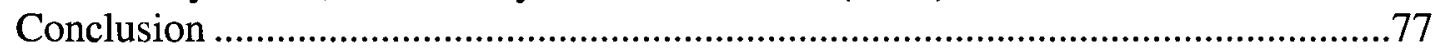

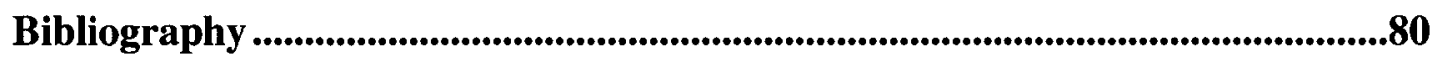




\section{List of Abbreviations}

CIC

Citizenship and Immigration Canada

FDM

Foreign Domestic Workers Movement

FWP

Temporary Foreign Worker Program

HRSDC

Human Resources and Social Development Canada

IMF

International Monetary Fund

LCP

Live-In Caregiver Program

NAFTA

North American Free Trade Agreement

OECD

Organization for Economic Cooperation and Development

SAWP

Seasonal Agricultural Workers Program

UFCW

United Food and Commercial Workers

UN

United Nations Organization 


\section{Contract, Migration and Citizenship: Farming and Caregiving Work in Canada}

The present heightened interest among political, legal and academic communities in international labour migration can lend outside observers the impression that longdistance migration is a phenomenon unique to our new, more globally-connected society. The positive and negative rhetoric surrounding economic and social processes collected under the term 'globalization' encourages us to place the origin of these processes at a time within living memory (Heckscher). This would be a mistake. The need for people to move long distances in search of the necessities of life has been a part of human survival since before the time of any historical record. Likewise, the transnational production and transport of resources and goods did not begin with the twentieth (or twenty-first) century, nor even with the Industrial Revolution. The story of migration for economic reasons as it occurs in the present does not begin with an international trade agreement signed by state leaders, nor does it involve a decision made by a transnational corporation. Migration for survival begins with the necessity experienced by those migrating, be they individuals, family groups or larger communities.

As economic survival has become linked to the earning of a wage in return for labour, the notion of migration for economic reasons has become linked to the notion of migration for employment. As territorially-based states, their borders and their institutions have evolved, long-distance movement for economic reasons has in some cases become 'international labour migration.' Nandita Sharma writes that

as borders became more fixed, migrants increasingly were portrayed as trespassers. In other words, as the nation became more homey to those seen as its members, migrants were made even more homeless. To be a migrant became tantamount to being a vagrant. [...] Migrants were thus strongly associated not only with losing their homes but also their moral standing (11). 
The present thesis places itself not at a point of historical rupture, but rather at one point in time during a continuous process of long-distance movement undertaken out of economic necessity, and the evolution of reaction to that movement among non-movers.

By the time Citizenship and Immigration Canada (CIC) explicitly took on the formal administration of international migration for work, it had already been occurring on an informal level for some time (Basok, 2002). However, the late 1960's and early 1970's marked a change in the way that the arrival and largely temporary stay of workers in Canada would be governed in two seemingly different industries: agriculture and livein home care. The state-run migration for work programs created at that time are known today as the Live-In Caregiver Program (LCP) and the Seasonal Agricultural Workers Program (SAWP).

From the perspective of the Canadian government, both programs were instituted at the behest of employers. At the time of its inception, the SAWP was seen as a godsend to farmers - Canadian farmers - who had sensitive crops to harvest and tend, and no people available to do the necessary work. The program also protected the ample food supply Canadians enjoy. The LCP was perceived by the Canadian public as a necessary solution to the lack of live-in nannies and caregivers available to care for children and the elderly. Part of the need for this kind of in-home care stems from the absence of muchneeded childcare spaces in daycare centres across the country (Stasiulis and Bakan).

\section{An 'Unfree' Freedom of Contract}

The SAWP and the LCP may both appear to provide a win-win scenario for workers in need of jobs and employers wishing to hire them. However, migrant work programs of this kind raise significant ethical and political questions. This thesis will 
explore some fundamental similarities between the LCP and the SAWP - specifically how aspects of gendered transnational citizenship may affect potential strategies of meaningful resistance and change by migrant workers. I argue that participants in both programs exercise transnational civil citizenship (Marshall) when they first contract with employers in Canada. However, once workers arrive, their citizenship is managed and limited through juridical and other means. The primary source of juridical control over worker citizenship is the work permit, which binds each worker to a single employer. Beyond this, worker citizenship is limited by the denial of relationships of interdependence between workers and their families, as well as the prevention of such relationships forming with Canadian citizens. In addition, SAWP and LCP participants' workplaces are defined as part of the private sphere of the home and family, in contrast to the broader public sphere associated with the full exercise of political citizenship (Marshall; Baines and Sharma). Following an analysis of relevant case law, I conclude that by disrupting the division between public and private as maintained by employers and the state, and by demanding recognition of affective relationships between workers and their families, workers stand to make significant advances in their working and living conditions in Canada.

Although the SAWP and the LCP are not the only migrant work programs in operation in Canada, I have chosen to focus on these for several reasons. Both programs are gendered in the selection process of workers and in the industries where they apply. The SAWP recruits mainly men with families in their countries of origin (Grez; Basok, 2002). The LCP recruits overwhelmingly female participants (Stasiulis and Bakan). The work done by farm labourers is traditionally designated as the work of men, while the 
care work accomplished by LCP participants has generally been considered the domain of women. In spite of these differences, the programs share important elements, such as the history of marginalization of workers in both agriculture and caregiving. This is reflected in the current exclusion of workers in both industries from certain labour and safety protections. Moreover, although participants in the SAWP and the LCP do not come from the same countries (CIC, 2006), their home economies share the effects of obligations under international treaties and lending agreements. Workers in both programs often come to Canada with the intent of supporting families who live in conditions of chronic underemployment. The SAWP and the LCP thus provide interesting points of comparison, which highlight the extent to which workers' circumstances in Canada are governed by gendered aspects of their citizenship.

As will be explained in greater detail in Chapter Two, the LCP and the SAWP each create a situation in which workers are bound to their employers in much the same way as indentured servants were confined in earlier times (Sharma). The denial of worker mobility is legally grounded in the worker's own juridical status as a non-citizen in Canada. Because work permits are tied to specific contracts, and employers have the power to terminate work contracts with relative ease, any complaints or attempts to improve working conditions by workers themselves can lead to repatriation or deportation, exclusion from migrant programs, and the possible consequence of grinding poverty for workers and their families. The absence of legal status beyond the temporary work permit can make migrant workers in certain sectors highly exploitable once they are in their host country (Sharma; Velasco). It is for this reason that some academics characterize the migrant workforce in Canada as 'unfree labour' despite the fact that 
migrant workers enter the contract of their own free will (Sharma; Basok, 2002; Satzewich).

The employment contract, freely-entered, is a central assumption of both the LCP and the SAWP. Workers joining either program are presumed in law to be capable of learning about the labour standards which apply to them and of ensuring (with the help of complaint-driven administrative processes) that their contracts are enforced. From the point of view of employers and the Canadian state, workers arrive as autonomous contracting individuals, unhindered by family concerns while on the job because family members may not accompany them. Participants arrive with the sole intention of working at their jobs and earning money to send home. For the duration of the workers' contract, 'home' remains their state of origin, even if the worker has lived in Canada for eight months of every year, for twenty years. This is a phenomenon which occurs under the SAWP in particular (Lee). The same is true for LCP participants even though they are allowed to apply for residency in Canada after completing two years of work in the program.

In this thesis, I will argue that the above view of the migrant employment contract is problematic for a number of reasons. First, the assumption that workers arrive in Canada as fully autonomous individuals denies the family relationships of interdependence at home which make migration for employment necessary for many workers. In practice, migrant work programs require that workers be motivated in their job search by the needs of family in the state of origin. From the initial hiring to the end stages of each program, both the LCP and the SAWP utilize the interdependency of 
workers and their families at home as a means of ensuring worker compliance while in Canada.

Second, neither program makes any allowance for the workers' potential to form lasting social relationships or bonds of interdependency while working in Canada under a temporary permit. Chapter Two outlines the means by which this is discouraged.

Finally, the employment contract, workplace practices, and employers' legal arguments in the court cases studied below, manage a distinction between private and public spheres which works in employers' favour to limit the application of labour standards and the potential gains in labour rights among workers. Nevertheless, I argue that the distinction can be disrupted through both worker resistance and employer retaliation. In analysing the court cases Dunmore (2001) and Fraser (2005) in Chapter Four, I argue that the counter-manipulation of the distinction between public and private can have an effect on the living and working conditions of program participants in

Canada. To that end, I use the concept of transnational citizenship as a means of describing the importance of certain forms of worker organization and resistance within the LCP and the SAWP.

\section{Theorizing Migrant Work: Transnational Citizenship}

Transnational citizenship is a nebulous term, so broadly defined in the academic literature that some may question its usefulness for analysis (Fox). It is also a 'trendy' term, linked intimately with notions of globalization as a forward-looking progression. It evokes a time which has not yet come and a hope for justice. In other words, although it lacks a clear definition, transnational citizenship is a loaded concept. 
The growth in appeals to transnational citizenship as a concept might be interpreted as a form of opposition to the exclusionary aspects of state citizenship (Stasiulis and Bakan). It may also express the recognition that today "[e]verywhere, the nation state itself - the entity to which the language of political citizenship refers - is eroded and challenged" (Hall and Held). Matthew Sparke writes that

With the increasing dominance of laissez-faire, market-based models of governance it seems we are witnessing the progressive erosion of national citizenship rights and the wholesale transformation of the constitutional qualities of social, political, and even, in some ways, civil citizenship. [...] In this context, citizens have been left able to vote in formal elections, but their elected governments have been strait-jacketed by trade law and obliged to curtail certain social programs and environmental protections. As a result, the meaning and quality of political and social citizenship has been eroded. (257)

The above quote refers to citizenship in terms of a relationship with the state.

Recognizing the transnational reach of many large corporations and the global scope of changes such as those Sparke describes, transnational citizenship can be seen as a tool for democratizing relationships with the state. However, it can also help us intellectually to move beyond forms of belonging which are territorially-based, and to understand how one citizen's private realm may overlap with the public sphere of another. Michael Hardt and Antonio Negri speak directly on the phenomenon of international migrant work. They write that state citizenship law is out of step with the socioeconomic reality of citizenship as experienced by migrants:

What we can see nonetheless is a first element of a political program for the global multitude, a first political demand: global citizenship. [...] Residency papers for everyone means in the first place that all should have the full rights of citizenship in the country where they live and work. [...] The demand is simply that the juridical status of the population be reformed in step with the real economic transformations of recent years. (400) 
They then extend this demand to include broader citizenship for all, including a social wage or "citizenship income, due each as a member of society" (403). This is reminiscent of the social citizenship enumerated in T. H. Marshall's classic piece on Citizenship and Social Class (Marshall, 1963). In their empirical study of migrant women in Canada, Daiva Stasiulis and Abigail Bakan describe campaigns by migrant and women's groups to improve international working and living conditions as exercises in "transnational dissident citizenship" (160-5). Transnational citizenship is a potentially powerful symbol for subordinated groups the world over because it provides a vocabulary for demanding the same standard of living as their dominant concitoyens.

Like the social citizenship outlined by Marshall in the twentieth century however, the transnational citizenship of the twenty-first remains more an aspiration than a reality. Stasiulis and Bakan (2005) emphasize that nation-states still exercise strong power over entry and the conditions of granting juridical citizenship. Migrant farm and caregiving workers enter and leave Canada under strict guidelines. For them, the border is ever present, even as they carry on their work in the heart of Canada's rural and urban communities.

The mixed reception of transnational citizenship among academics is as much due to expectations of what the concept should be able to 'do', as to the (related) disappointment in current economic and political circumstances which fail to match the ideal promised by a citizenship freed from territorial limits (Stasiulis and Bakan; Fox). A common slogan of activists expresses the hope of transnational citizenship, while confirming the lived reality: "No borders! No nations! Stop the deportations!" 
A related concern is expressed by Donna Baines and Nandita Sharma (2002). They write that the use of citizenship (including transnational citizenship) as a concept for emancipatory purposes may be inappropriate. This is because the elements of full citizenship famously outlined by Marshall have traditionally only been available to a small and restrictively defined part of European and North American populations.

T.H. Marshall's use of social and other forms of citizenship were not gender or racially neutral and did not apply to all individuals in an equal and universalistic manner. [...T] The concept of citizenship contained gendered and racialized assumptions embedded in the policies and relations of the emerging welfare states [...] Despite the lively debate that has occurred within feminist and anti-racist literature, most of the debate on social rights and citizenship continues to operate as if these concepts have been largely liberatory and provided, or could potentially provide, equal benefit to all (79).

Taking the above critique into account, I use the concept of transnational citizenship as a tool of analysis, rather than embracing the idea itself as a means of emancipation. I argue that migrant workers under the LCP and the SAWP begin their journeys to Canada as transnational citizens in the civic sense - in the sense that they have sufficient legal standing to enter transnational work contracts. However, as anticipated by Baines and Sharma, the transnational citizenship of migrant workers in Canada is in fact gendered and racialized, as is that of many individuals who are 'full' Canadian citizens in the strict legal sense. This thesis explores two aspects of that gendered and racialized citizenship which are familiar to feminist theorists: the denial of interdependency among individual contracting workers, mentioned above, and the distinction between private and public spheres of citizenship, explained directly below.

In the second and third chapters I will explain the means by which migrant workers are discouraged from forming a stable private life while in Canada. These include geographic isolation in rural areas, social isolation within employers homes in 
urban areas, and the selection of candidates for work who have strong family ties with their states of origin - ties which encourage workers to keep their jobs while in Canada and (in the case of the SAWP workers) to return home when the work is over. At the same time, the supposedly 'public' citizenship sphere of the workplace is shielded from the full application and enforcement of labour standards through the fact that it is a private home in the case of the LCP, and through the discourse of the 'family farm' in the case of the SAWP. In both programs, workers are first denied the development of a private sphere of life by immigration restrictions. Following this, their exercise of public workplace rights is hampered by employers' varied success in having the workplace legally-understood as a private sphere.

'Private' in this sense refers not to private ownership, which is characteristic of all employment relationships. In this thesis, I refer to the private in feminist terms. It is a sphere which is traditionally hidden from view, in which labour is generally un- or underremunerated and not quantified in the standard terms applicable to wage labour. It is also the sphere most commonly excluded from citizenship in the traditional sense (Baines and Sharma). However, the private is also a place where strong emotional bonds form, in which people are interdependent, helping one another without the expectation of strict reciprocity between members. In the employer's private sphere, a worker may be considered 'like one of the family' as in the LCP, but as a consequence may have little privacy, and be unable to build a private sphere of his or her own. I argue in the third and fourth chapters that the LCP and the SAWP both operate in industries where there is a legal privileging of the sanctity of employers' private family homes and farms over workers' public rights as employees. 


\section{Method and Chapter Outline}

In making the argument outlined above, I rely on a variety of sources, including empirical studies into migrant experiences (Basok, 2002; Stasiulis and Bakan; Anderson, 2000), World Bank and United Nations statistics, as well as reports by the United Food and Commercial Workers union (UFCW), which has been involved in organizing migrant agricultural workers for several years. The two main primary legal sources appear in chapter Four. They are the Supreme Court of Canada case, Dunmore (2001), and the lesser-known Ontario case of Fraser v. Canada (2005). I also refer to the factum of the Ontario government, as well as affidavits filed by both parties in Dunmore for a more indepth understanding of the role of the 'family' workplace in employer labourmanagement strategy.

Following state legal classification and popular usage, in this thesis migrant workers are distinguished from immigrant workers by the intended legal purpose of their stay in Canada. The Canadian state has several different paths by which a person from another country can legally enter and reside. Immigration refers to those paths which may lead to more permanent status such as citizenship or residency. The 'family class' and 'economic class' immigration under s. 12 of the Immigration and Refugee Protection Act (2001) are among these.

The work programs studied in this thesis do not fall under the above categories. Chapter Two explains the legal and social conditions which help differentiate between migrant work, and immigrant work. The former involves the temporary presence of foreign nationals in Canada, for the sole purpose of working at a particular job. Most jobs performed by migrant workers are in industries which face shortages in available 
Canadian workers, such as farming and home care (Basok, 2002; Sharma). Reasons for these perceived labour shortages are explored. The LCP and the SAWP are unique programs in that they are industry-specific, targeting home care and agriculture in a managed migration process. Canada also operates a Temporary Foreign Workers Program (FWP) which authorizes migrant work in the country on a temporary basis in industries as diverse as film, business administration, and agriculture. Although agricultural workers can be admitted through the FWP, Chapter Two will focus on workers admitted under the SAWP and LCP only.

The chapter begins by outlining the objectives of the Canadian state in setting up the migrant work programs. The passive role expected of workers in relation to their own conditions of work is explained. Following this, I offer a sampling of factors which lead to the decision of a worker to seek employment abroad. The effects of international financial institutions' lending policies, as well as the restrictions imposed on agricultural subsidies under international trade agreements are discussed. I argue that migration for work to wealthier countries such as Canada should not be seen as a unidirectional movement (of workers). Rather, it is a cycle which begins with decisions imposed by wealthy countries and lenders on less-powerful nations. The example of corn prices in Mexico illustrates how Mexican farmers put out of business by wealthier NAFTA signatory countries must then move to those same countries to work for their competitors in agriculture under programs like the SAWP. The movement of currency from Canada and other wealthy countries to the home countries of workers is also outlined, with emphasis on the fact that migrant remittances often outweigh foreign direct investment in 
their home states. The public economic recovery of home states is thus dependent on private currency flows between close family members across borders.

Finally, the motivations of employers for hiring migrant workers are discussed. Here it becomes evident how stigmatized and difficult the work done under the LCP and the SAWP can be. For a variety of reasons, farm labour and home care share the dubious distinction of being among the least desirable occupations in Canada, even for individuals with little formal education and few other work opportunities (Satzewich; Status of Women Canada: Part II). Hence, the decision to 'import' willing workers from other countries, workers whose home state economies perhaps do not offer the same opportunities and protections as in Canada, and whose level of desperation to find work would be higher than that of their Canadian-citizen counterparts.

This is a story familiar to those who study the processes of production and social change commonly referred to as 'globalization'. It is a story of people today who, like others in earlier times, have been forced to migrate far from home in order to provide an economic future for themselves and their families. Finding a job, many migrant farm workers must deal with dangerous working conditions and often must live in employerowned housing located far from centres of commerce. Live-in caregivers experience the long working hours and the lack of privacy that comes from living in their employer's home, coupled with the invisibility so often associated with domestic work (Blackett). The potential for employer abuses in both industries is heightened by the likely consequences of being fired for the worker, which include repatriation or deportation to their home country (Basok, 2002; Stasiulis and Bakan). 
In using categories like 'migrant' to define types of work (and types of workers) it is helpful to keep in mind the argument put forward by Sharma (2006), that use of the term 'migrant' artificially separates those to whom the label is attached from 'citizens' who are at home in the countries where migrants work. With this in mind, Chapter Three begins with an analysis of citizenship meaning in Canada, including the Canadian Citizenship Act. The use of citizenship to separate 'insiders' from 'outsiders' is discussed. With reference to Vic Satzewich (1991), I then outline the means by which juridical citizenship has been used as a tool of labour management since post-World War II in Canada. The LCP and the SAWP are cast as the latest incarnation (perhaps the perfection?) of a system of labour relations which ensured compliance through the use of citizenship status as an incentive and means of coercion.

I then move on to discuss the issue of interdependency and the social exclusion of migrants working in Canada. The means by which migrants are discouraged from forming lasting social relationships are explained. Particular attention is paid to the 1999 Supreme Court of Canada case of Mavis Baker, a Jamaican woman who gave birth to four children in Canada while living there without immigration status. The importance of treating domestic and live-in care workers as 'one of the family' and autonomous at the same time in Canadian policy is outlined. I then proceed to introduce the public-private distinction as it is experienced by migrant workers on farms and in homes in Canada. The issues of privacy and labour protections mentioned earlier in this introduction are fleshed out, with reference to a UFCW report on the status of farm workers in Ontario as an example. I conclude that gendered citizenship provides a useful analytical perspective which highlights the importance of this public-private distinction in the lives of workers. 
Chapter Four takes the observations on citizenship, interdependency and the public/private distinction further in commenting on two cases, Dunmore (2001) and Fraser v. Canada (2005). In Fraser v. Canada, a case which deals with parental leave benefits, I argue that feminist claims about aspects of social citizenship including parental leave should take into account the differences in citizenship as it is experienced by Canadian-born women, versus migrant workers. In showing how the Ontario government sought to exclude farm workers from collective bargaining rights in Dunmore, I argue that the discourse of the 'family farm' was integral to the government and employer litigation strategy. Affidavits filed in the case are referred to in support of the idea that the designation of agricultural employees' workplaces as 'family' spaces works against their efforts to gain full participatory citizenship in the workplace and broader Canadian society. A similar argument is made about the LCP, with reference to the legislative frameworks governing the program itself, as well as the nature of the work performed. I conclude that commonly held views of interdependency and the public/private as experienced by migrant workers can be effectively disrupted as part of continuing efforts to improve conditions while in Canada. 
Origins: the Economic Migration Cycle and Canadian Labour Shortages

\section{Introduction}

The SAWP and the LCP are legally separate programs, apart from the fact that each is managed by the federal government in cooperation with the governments of workers' countries of origin. ${ }^{1}$ The identity characteristics of worker participants in each program may differ significantly. While the SAWP counts overwhelmingly male participants, most workers entering Canada under the LCP are women. Agricultural migrant workers mainly come from Mexico and the Caribbean, while the majority of live-in caregivers admitted under the LCP are from the Philippines (CIC, 2006).

Likewise, the industries where participants work are distinct: farming tomatoes and caring for children and the elderly are vastly different occupations, employing different skill sets and raising different assumptions about the gender of their participants.

Nevertheless, by the end of this chapter, it should be clear that important similarities exist between the social and legal situations of migrant farm workers and migrant caregivers while in Canada. To make the above clear, it is necessary to provide an account of each program, their parallel development under Canadian immigration law, and the social context in which workers choose to come to Canada under each.

\section{Objectives: Canadian State}

Central to most migrant work programs is the existence of a contract (Basok, 2002; Anderson, 2000; CIC, 2002). For this reason, it can be helpful in studying the SAWP and the LCP to begin with a fundamental principle of liberal contract theory: every contract begins with its parties. In this case the two main parties are a migrating

\footnotetext{
${ }^{1}$ The government of Quebec is also involved in administration of both programs through an additional immigration regime, however blanket changes to either program are approved under federal law.
} 
worker in search of a job and a Canadian employer wishing to hire. The meeting of parties' minds to form a shared objective is essential to the creation of their agreement (Ibbetson). The fact that the agreement in our case happens to be a contract of employment does nothing to change this important beginning from the liberal point of view. In theory, employer and employee come together for the sake of their mutual interest: the employer having a need for labour and the money to pay for it, and the employee having a need for wages and labour to offer in exchange.

In the case of migrant work programs, the Canadian state also has a strong influence on the contract, despite the fact that it is not a party to individual agreements between workers and employers (CIC, 2002; Basok, 2002). It is through the intervention of the Canadian administrative apparatus that migrant workers' journeys to Canada are facilitated, and their citizenship while here is delimited and managed. The impact of Canadian immigration law on the experiences of workers as transnational citizens cannot be underestimated. It lays out the public conditions of mobility and economic power under which their private employment contracts are carried out (Stasiulis and Bakan).

Many people already have an image in mind of what the work of migrating people might entail, where migrating workers come from, and what kinds of job skills they have (Sharma). The agricultural and domestic work done by workers under the SAWP and the LCP, respectively, fit well with this image - that of difficult conditions experienced by people working far from their place of origin. The United Nations International Convention on the Protection of the Rights of All Migrant Workers and Members of their Families (Convention) gives a similar impression. Article 2(1) of the Convention defines a 'migrant worker' as "a person who is to be engaged, is engaged or has been engaged in 
a remunerated activity in a State of which he or she is not a national." Protections under the Convention include a right under article 11 not to be held in slavery or servitude, in recognition that these forms of domination present a real danger for many migrating workers.

Canada has not signed the Convention, despite public pressure to do so. The Canadian government response when asked why it has yet to sign is as follows:

Canada does not have a class of Migrant workers per se. Any non-Canadian who is authorized to work in Canada is protected by the same employment standards legislation as Canadian workers, and has the same access to government programs and services for workers. As such, we have no immigration policies in this regard that are inconsistent with international human rights instruments and have no discriminatory policies and practices against migrants in our laws for us to remove (Canadian Heritage).

If we consider the above comment in light of the available literature on the LCP, the SAWP and the Temporary Foreign Worker Program, it is clear that Canada does, indeed have a class of 'migrant' workers - whether or not they are designated within a single immigration category (Sharma; Baines and Sharma; Basok, 2002, 2004; Stasiulis and Bakan; Satzewich). As for the claim that workers are protected by the same standards as Canadian employees, it will be demonstrated below that this statement is indefensible, both on both legislative and empirical grounds.

One concern which is substantiated in law is that the Convention makes no distinction between federal and unitary states. Because Canadian labour legislation is a provincial matter and not subject to federal control, a federal government signature would mean little without the cooperation of every province in which migrant workers were hired (December 18.net). This presents a challenge to Canadian ratification, albeit one which could be overcome through negotiation and public input. An alternative 
explanation for the refusal is that if Canada were to sign the Convention, certain restrictions under programs like the SAWP and LCP would violate the treaty (McQueen).

If Canada were to ratify these conventions, two important aspects of the SAWP that currently work to maintain the vulnerability of Mexican migrant workersthe denial of a right to collective bargaining and the inability to circulate in the labour market-would be in violation of the country's international legal obligations (McQueen, 10).

In the LCP as well, workers' permits are tied to individual employers, thereby preventing mobility of live-in caregivers in the labour market. The right to bargain collectively is held by some agricultural workers in Canada today, notably in Quebec and Manitoba, where SAWP participants have applied for union certification in 2007. However, in Ontario, where the majority of SAWP participants work, that right is still effectively denied by the provincial government (Fraser v. Ontario).

Canada's stated reasons for creating migrant work programs begin with the concerns expressed by Canadians and not those of program participants themselves (Sharma). Despite the opportunities each program offers to migrating workers, the SAWP and the LCP were each set up to fill a labour shortage as perceived by Canadian employers (Basok, 2002; Stasiulis and Bakan; Sharma). A recent Citizenship and Immigration Canada (CIC) overview of migrant work programs is telling:

Over the years, various initiatives have been introduced in order to respond to the needs of Canadian employers and the increasing mobility of the global labour force. Citizenship and Immigration Canada ... and Human Resources and Social Development Canada (HRSDC) have worked together to design the Temporary Foreign Worker Program to accommodate new labour market challenges at a speed that will support Canadian employers' efforts to operate effectively (CIC, 2006).

The report goes on to compare the 'stocks' of available migrant workers in Canada from one year to the next: "Stocks by gender differ from the trends identified in 
the foreign worker flow data. Overall, both males and females have seen continuous growth in their respective stocks of workers [...]" (CIC, 2006). The word 'stock' is used here to differentiate between the number of migrant workers already in Canada (the 'stock'), and the number of people who enter for the first time (the 'flow' of workers) in a given year. Nevertheless, the language used by CIC above also emphasizes the passive, background role which workers seem expected to play in the context of migrant work programs like the SAWP and the LCP. They are not, we might assume, legal subjects in the above context, but rather a group of legal objects for trade (Anderson, 2000; Velasco). In a reversal of this common approach, below people's motives for travelling for work are dealt with before addressing employers' reasons for wishing to hire them.

\section{Objectives: Migrating Workers}

The decision to work in Canada begins in each worker's country of origin.

Different people have their own reasons for working abroad, and so the present description can only be taken as a generalization. Nevertheless, the empirical data available on migrating people's experiences can help to establish an informative picture of the objectives of workers who enter Canada under the SAWP and the LCP. Economic and historical factors in so-called labour-sending states have a common influence on workers who come to Canada from those states. Migration to Canada for temporary work under the two programs is largely motivated by a combination of difficult economic conditions and lack of paying work in the state of origin, a need to provide for self and family, as well as an inequality of wealth between Canada and the sending state. ${ }^{2}$ These

\footnotetext{
${ }^{2}$ Of course not all people who move for work live in poverty. A business executive who travels from the United States to Canada is also a migrant worker, however this executive is absent from the 'stock' of workers labelled as 'migrants' (Sharma).
} 
factors combine to make moving to Canada temporarily for work an attractive option, even when one considers the disadvantages and injustices outlined later in this chapter.

Movement for work is a highly personal choice, but it takes place in a broader economic context over which workers have little or no direct control. Family responsibilities figure highly in the decision to leave home for work elsewhere. In the words of one woman who left the Philippines to work as a caregiver in Singapore, "[Working in the Philippines was] only for your own self. You could not help others. But [working] there, you could help everyone" (Asis et al., 2004: 205). In an economic climate where the Canadian dollar is stronger than the local currency, having a member of the family abroad and able to send money home represents financial stability and a possible way out of poverty. Thus, although workers are free to choose whether they would like to participate in the SAWP or LCP, significant pressure is on many of them to ensure the future economic well-being of their relatives and broader community. This stands in contrast to the typical liberal understanding of the employment contract as an agreement between two discrete individuals. When a worker comes to Canada under the LCP or the SAWP, the contract is signed not for his or her sake only, but for that of a host of 'silent partners' at home. The reasons why the families of migrants may be at risk of experiencing poverty are complex. However, this risk can to some extent be associated with the economic hierarchy in effect between 'labour-receiving' states like Canada and 'labour-sending' states of the global South.

Both the LCP and the SAWP recruit workers from countries which are less wealthy and less powerful than Canada (McQueen; Stasiulis and Bakan). For example, the majority of live-in caregivers who enter Canada under the LCP are from the 
Philippines, while most SAWP participants are from Mexico (CIC, 2006). The SAWP in particular is the product of international agreements between Canada, Mexico, and several Caribbean states (McQueen; Basok, 2002). The economic conditions faced by workers in the Philippines, Mexico and other countries of origin are difficult. A combination of state indebtedness and an inability to profitably farm crops that once flourished in the home country forces many agricultural and other workers into poverty. The negative effects of intervention by international financial institutions are also documented.

In Mexico for example, prior to the implementation of the North American Free Trade Agreement (NAFTA), small farmers in rural areas were able to farm crops such as corn, beans and fruit to sustain their families and to sell in local markets. Farmers were not rich, but government agricultural subsidies ensured that price floors protected the small farms which could not otherwise compete with imported food from the U.S., China and other countries. However, a combination of International Monetary Fund (IMF) lending conditions and NAFTA treaty obligations forced the Mexican government to do away with most of the subsidies that had kept small Mexican family farmers in business (White et al., 2003).

Real corn prices have fallen more than 70 percent (from 732 pesos in 1994 to 204 in 2001) since NAFTA began. This means that corn producers and their families are living on less than one-third of the income they earned in 1994 (White et al., 2003: 14 , note omitted).

A direct result of the fall in prices and farmers' incomes is that more and more families are required to send members outside of the country to find work. Because Mexican farmers cannot compete with imported produce from places like Canada and the United States, in some cases they leave their own farms to work for their international 
competitors (Basok, 2002; White et al., 2003). ${ }^{3}$ In Mexico, the employment rate for adults is far lower than in Canada, with the underemployment rate sitting at about $25 \%$ (OECD, 2003).

The SAWP is not the only means by which farmers may migrate out of one country to work in another, however it is popular with workers for several reasons. Perhaps foremost is the security offered by the program, in comparison with undocumented migration to Canada and the United States. Participants in the SAWP are able to have frequent telephone and mail contact with families. They are not subject to the same pressures as workers who must live 'underground', concealing their identities for fear of deportation (Basok, 2002). Moreover, independent, documented migration to the United States and Canada often costs a great deal more than participation in the SAWP. The SAWP is accessible to workers with very limited education and financial resources because most travel and accommodation costs are paid for by the employer. This accessibility, coupled with the program requirement of financial need, means that most workers who participate in the SAWP come from the same socioeconomic class (Basok, 2002: 102-104). They are also men in the majority, although participation among women is growing (CIC, 2006; UFCW, 2004). Unlike the SAWP, and in addition to the above benefits, the LCP offers the advantage of allowing workers to apply for permanent residency once they have completed a two-year term of live-in employment (although acceptance is not guaranteed).

\footnotetext{
${ }^{3}$ A similar situation is documented in the film, Life and Debt, set in Jamaica (Black). This film tells the story of farmers who have seen their domestic produce market disappear almost overnight following trade 'liberalization' measures imposed by the IMF as the lender of last resort in the region. Jamaica is a participant country in the SAWP.
} 
The situation in the Philippines is similar with respect to the impact of international financial obligations on people throughout this labour-sending state. As one commentator remarks:

[T]he International Monetary Fund/World Bank imposition of structural adjustment programs in the Philippines has also intensified the misery of our people with deathly poverty and massive unemployment. [...] So, given these difficult economic and employment situations, our workers are conditioned and oriented to become so-called 'docile, cheap and exportable labour'-and this is the kind of labour that is attractive to labour-receiving countries like Canada (Velasco: 131).

Today migrant workers are integral to the economy of the Philippines. Filipino migrant caregivers, which compose the majority of LCP participants, have a special role in ensuring the survival of their families and concitoyens.

In fact, caregivers from the Philippines support a third of the population of that country. Three million women working overseas (most of them caregivers) send $\$ 5$ billion home to their country, managing to support about 20 million people in a country with a total population of 65 million (Status of Women Canada: 1.2.1.1)

Referring to the LCP, Citizenship and Immigration Canada states that as of 2006, “foreign workers from the Philippines [...] dominate the stock data, accounting for 16,458 of the 19,224 total number of foreign workers in the program" - of which the vast majority are women (CIC, 2006). The World Bank 2005 estimate for total (men and women) remittance flows to the Philippines is 13.3 billion U.S. dollars (World Bank Data, 2006). The 2005 estimate for migrant remittances to Mexico is even higher: 18.9 billion U.S. dollars (World Bank Data, 2006). "[I]n aggregate, remittances are more than twice as [sic] the size of international aid flows" (World Bank Summary, 2006: vii).

At these levels, remittances sent home by migrant workers not only support families on an individual basis, but are a much-needed source of foreign currency in workers' states of origin (Wodon et al.; Stasiulis and Bakan). Hence, the willingness of 
participant governments to enter labour migration agreements on Canadian terms (McQueen). This is done in the face of demands on states under international trade agreements and by lenders of last resort to cut back on measures designed to alleviate the poverty that makes migration for work necessary. As IMF borrowing conditions are imposed by wealthy nations such as the United States, as tariffs and subsidies are eliminated under agreements such as the NAFTA, and as state governments weaken social protections to attract foreign direct investment, economic necessity leads many people to move temporarily to the very countries which are in part responsible for their inability to find work at home. In the process, migrant workers the world over currently send more Canadian and U.S. dollars to their home states every year than are attracted by their governments in hard-won foreign direct investment (Familiar). Transnational companies can close plants and move production operations and investment from one country to another at a whim. Perhaps less-wealthy countries do better to rely on the strength of migrant workers' family bonds, rather than on international trade agreements and on 'gifts' from foreign private sector organizations.

The above facts and figures are recent, as academic and social consciousness of the impact of the NAFTA and institutions like the IMF and World Bank also appear to be (Heckscher, 2002). It is tempting to connect the phenomenon of temporary migration to Canada directly to a seemingly new set of social and economic processes: globalization. Surely, we might think, this is a new outcome which will sooner or later settle down as social conditions in newly opened markets improve. We should avoid this easy conclusion. A prominent political leader from the Philippines, Jose Maria Sison has stinging words for those who place the origins of present-day global economic conditions 
at the beginning of the 1980s. In his opinion, what we now call 'globalization' has its origins in a much older system of colonialism and imperialism:

Globalization is a slick and shallow term. It glosses over the reality of modern imperialism or monopoly capitalism ... Corporate executives, bureaucrats, bourgeois academic pedants and imperialist-funded NGOs have circulated the term globalization as if it meant a new shiny and amazing thing (cited in Artner, 2004: 251).

\section{Objectives: Employers}

There is a certain dramatic irony to the difficulties of migrant workers and their families, as they find their own problems distortedly reflected in the concerns of Canadian farmers and families with children. The urgent problems that need fixing, from the point of view of Canadian employers, are those of the Canadian 'family farm' which faces ruin unless it can obtain the labour force needed for a successful harvest. They are the problems of Canadian women who also must support their families financially, and need someone to do the labour at home while they are out at work. It is these concerns which shape the design of the SAWP and the LCP by the Canadian government.

Tanya Basok (2002) has described migrant agricultural work as a "structural necessity" in Canada: a form of labour without which the farming business could not survive. Agricultural migrant work is an essential part of Canadian society, yet it is also practically invisible from the point of view of the public. Despite advances in technology which have enabled farmers to produce more with less labour, some aspects of agriculture remain labour-intensive. Even in the twenty-first century, many crops are simply too fragile to be harvested mechanically (Basok, 2002). The harvesting of tomatoes and cucumbers, as well as many other crops, is still largely done by hand. 
Many urban dwellers grow their own tomatoes during the summer, lovingly tending a few potted specimens in the hope of harvesting five, ten or more tomatoes by the end of the growing season. Imagine, however, the work involved in producing the tomato crop required year round by companies such as Heinz, makers of one of the most popular ketchups on the market and a major consumer of Ontario tomatoes (Basok, 2002). Each tomato must be hand-harvested, at peak time, with little room for mistakes. As a group of Ontario farmers explained to Basok,

With tomatoes they ripen seven days a week. They don't just ripen from eight o'clock Monday morning till 4 o'clock on Friday. They ripen all the time. [...] I think we need reliability. We can't risk. The crop is so sensitive. The day or two off can do a lot of damage. We can't afford to be without help for a short time (2002: 55).

Farmers consistently have difficulty finding local people willing to work the long hours necessary for a successful harvest. The presence of pesticides and heavy equipment make it a dangerous, even deadly form of work (Verma; UFCW, 2004). Until June 2006, Ontario farm workers were excluded from health and safety legislation such as the Occupational Health and Safety Act, meaning that they did not have the right to refuse unsafe work without fear of employer reprisals (Verma; Ontario Ministry of Labour, 2006). Due to the recent nature of this change, it is unclear what effect the new inclusion will have on working conditions - nor are present workers necessarily aware of their new rights. Farm work is also underpaid in comparison with physical work of similar intensity in other industries (Verma).

An employee who may leave at any moment presents an economic risk to the grower which many would prefer to eliminate altogether. Basok (2002) argues that aversion to this risk of employee turnover is what makes the tightly-controlled labour of 
migrant workers a "structural necessity" to agriculture in Canada (see also Satzewich). The SAWP is one state legal response to this perceived necessity.

The LCP does not involve such a direct relationship to production in Canada, however the perceived need for the program among employers is strong. The concern over the ability of employees to quit at will is equally present. Live-in caregiving is not the same as 'domestic work' under the standard definition. Bridget Anderson (2000: 15) explains that the International Labour Organisation definition of domestic work includes duties such as shopping and cleaning, but says nothing about caring work. On the other hand, live-in caregivers are expected to do caring work as their main occupation. The line between 'domestic worker' and 'live-in caregiver' is blurred in Canadian law all the same. In Quebec health and safety law, a domestic is defined as "a natural person engaged by an individual for remuneration, whose main duty is, in the dwelling of the individual, 1) to do housework, or 2) to care for a child or a sick, handicapped or aged person and who lives in the dwelling" (Act respecting industrial accidents and occupational diseases). The purpose of this definition is to exclude 'domestics' from workers' compensation coverage in the province, much as farm workers were excluded until recently in Ontario.

Caregiving work may seem on the surface to be less difficult than agricultural labour. It is less physically dangerous, certainly. However, it is still an exhausting job. One caregiver working in Europe provides a clear description of the reality of live-in work and the stress of being constantly being 'on call' for the employer:

You're working the minute you open your eyes and the minute you close your eyes. You keep your strength and your body going so that you will finish work...you will keep on waiting to your employer till they get sleep because, although you finish your work, for example you finish ironing, everything, putting 
the children to bed or the elder person in bed, even if you put them in bed at ten o'clock still there are other members of the family. So you keep on observing, 'Oh, can I sleep or maybe they will call me to give them food or to give them a yoghurt'...And even if you are sleeping if you are already sleeping still you can feel that you are still on duty (Anderson, 2001: 22).

This may help to explain why, again, so few Canadian citizens with other options are willing to engage in this kind of employment. Anderson makes the important point that domestic workers (including care workers) "often perform tasks it is unlikely that any woman with a choice would be prepared to undertake" as part of their work routine (2000: 16, emphasis in original).

\section{Program Design}

In both live-in caregiving and agricultural work, the fact that those who do have a choice generally will not remain in these occupations for long has led the Canadian state to design the SAWP and the LCP to include restrictions on employment mobility for migrant workers. These and other migration for work programs create a state of 'unfreedom' for workers entering Canada on a temporary basis (Sharma; Basok, 2002). This is true even in the case of the LCP, which offers the possibility of eventual citizenship to participants in the program. From the point of view of employers, the SAWP and the LCP are necessary because no one in Canada who has a choice would do the kind of work that is demanded of migrants in these jobs.

The basis of the SAWP is a set of agreements and memoranda of understanding with Mexico and Caribbean states which allow for an exception to regular immigration laws, and for the creation of a special legal category of migration into Canada (McQueen:

8; Verma). Within these memoranda of understanding, certain responsibilities are divided between the states involved. The administration of the program is conducted by the 
Foreign Agricultural Resource Management Service (FARMS) in most of Canada, and its equivalent, called FERME in Quebec, New Brunswick and Prince Edward Island (Basok, 2002; McQueen; Justicia, 2007). FARMS is a non-profit organization which works as a central broker, putting farmers in touch with governments and workers, as well as facilitating the hiring and movement of individuals. FARMS is funded by employers, and Human Resources and Social Development Canada (HRSDC) retains significant control over management of the organization (McQueen; Basok, 2002: 37).

Responsibility for the well-being of workers who come to Canada is shared between farmers, the Canadian government and the governments of sending states, whose consular officials are charged with responding to worker complaints and assisting in the resolution of disputes and family emergencies (Basok, 2002; McQueen). Alison McQueen (2006) argues that within the bilateral inter-state agreements on which the SAWP is founded, the balance of power is held by the Canadian federal government, which sets most of the conditions and has significant control over daily administration. Recall that migrant remittances are a valuable source of currency in labour-sending states as well, which may explain why consulates are not strident supporters of workers who make complaints about their conditions. This leads to worker dissatisfaction with the perceived inability or unwillingness of consular officials to take complaints of safety hazards and bad working conditions seriously (Basok, 2002; Grez).

The process begins simultaneously in Canada and in the home state of the worker. In Canada, a farmer contacts FARMS with a request to hire workers under the SAWP (Basok, 2002). The farmer must be able to demonstrate a lack of available Canadian workers to fill the job. Following the request to FARMS, the grower is guided through a 
process of recruitment, including advice on how to estimate labour requirements and the type of worker accommodations which are required under the program (FARMS). In his or her home country, a worker applies through the ministry of labour offices for admission to the SAWP. Admission is selective; the ideal candidate is a married father with limited education and great financial need, which ensures that the worker will return home at the end of the work term (Grez). This description fits many Mexican day labourers who have seen their work disappear due to changes in agricultural production in Mexico (Preibich; Basok, 2002). Workers who participate in the program are reimbursed for their airfare to and from Canada, provided that they complete the work term.

The farmer has an opportunity to name particular workers which he or she would prefer to hire (FARMS, Basok, 2002). Once a worker is selected, the worker is issued a Canadian visa which entitles him to work for a limited period of time in Canada, for one specific employer. If the worker wishes to change employers during the season, he must file for a new work permit, and both employers must agree to the change (Lee; Basok, 2002; McQueen). This arrangement makes it difficult for workers to leave one employer for another while staying in Canada, a fact which ensures a lower risk of employee turnover for farmers (Satzewich). The average work term may last between three and eight months, with workers returning in subsequent years; many workers spend more time on Canadian farms than at home with their own families (Lee; Gutierrez).

The LCP also involves a selection process which begins in both Canada and the worker's home country. To be admitted under the LCP, a worker must meet certain conditions. She must have the equivalent of a high school education, post-secondary 
education or 12 months of relevant work experience, sufficient knowledge of English or French, and a contract with a Canadian employer (CIC, 2002). Individual families wishing to hire a caregiver can obtain information on how to do so from Citizenship and Immigration Canada, or they can use the services of a selection of private employment agencies based in Canada (Stasiulis and Bakan). The agency may introduce the employer to a caregiver already in the country, or to a potential caregiver living abroad. As in the case of workers under the SAWP, LCP participants who are hired through an agency are subjected to greater scrutiny than are their employers. While employers have the opportunity to name the worker they would prefer to hire, workers have little choice when it comes to their own employment and are not given a great deal of information about their potential employers (Stasiulis and Bakan).

The LCP differs significantly from the SAWP in one important aspect. The LCP holds out the possibility of permanent resident status for workers who complete the standard 24-month work term (CIC, 2002). Following completion of the work term, a live-in caregiver can apply for permanent residence in Canada, a status which gives her the right to remain in the country, and the possibility of sponsoring family members to join her later. Permanent residency also allows an individual to choose employment within the broader Canadian labour market. A permanent residency application by a livein caregiver is not guaranteed acceptance by CIC, however it is still a powerful incentive to participants. SAWP workers are instead obliged to return to their countries of origin following the end of their employment contract, even if it is only for the four months between work terms. While the LCP opens the door for possible juridical citizenship status in Canada, SAWP participants are forever designated as temporary workers. 


\section{Program Concerns}

The SAWP in particular has been characterized as a model of 'best practices' for foreign guest worker programs, providing all involved with benefits. This understanding is underlined in a 2004 joint statement by Canada and Mexico, on the $60^{\text {th }}$ anniversary of diplomatic relations between the two countries:

The Seasonal Agricultural Workers Program (SAWP) is a clear example of the advantages of cooperation and a symbol of the strength of our bilateral relationship. For 30 years, the SAWP has provided significant economic and social benefits for both Mexicans and Canadians, relieving labour shortages in Canada and offering rewarding employment opportunities for Mexican workers. In this anniversary year, the program now stretches from the East coast to the West coast, with the employers in British Columbia for the first time involved in the program (Privy Council Office).

Nevertheless, both the SAWP and the LCP contain expressly coercive elements. Workers under both programs face the continued threat of being sent home early or excluded from Canada in later years. Under the SAWP, following a one-week probationary period farmers have the ability to send a worker back to the country of origin at any time (UFCW, 2004), in spite of the fact that farm workers are covered by certain provincial employment standards (Gutierrez). Thus, farm employers enjoy a coercive power over and above the traditional employers' threat of termination. Under the LCP a similar threat exists. Live-in caregivers receive some protections with respect to termination under provincial employment legislation, however enforcement is difficult. A live-in caregiver without a job can be deported from Canada. If a worker is unjustly dismissed, for example in violation of the Quebec Act Respecting Labour Standards, ${ }^{4}$ she must still find a new employer (and a new work permit) while waiting for her case to be treated by the

\footnotetext{
${ }^{4}$ Article 122 of the Quebec Act Respecting Labour Standards prohibits firing a worker on several grounds, including pregnancy, exercise of rights under labour legislation and taking time off to care for family members. This protection exists regardless of the employee's length of service.
} 
Labour Standards Commission. This makes for an imbalance of power in both programs the likes of which Canadian resident employees may seldom experience.

Moreover, under the SAWP, upon returning to the country of origin every worker must submit to the home government a sealed envelope containing an evaluation filled out by the employer. This evaluation will have an influence on the worker's continued eligibility for the program. Basok (2002) argues that the framework of selection and evaluation creates a circumstance in which workers compete for their employer's favour, and in which migrants are afraid to complain about bad conditions for fear of being sent home or excluded from the program the following year. Poverty and lack of employment opportunity are major influences on a worker's decision to come to Canada. The prospect of an individual worker's rejection from the program can therefore imply dire consequences for entire families.

Added to the threat of termination and repatriation or deportation from Canada is the fact that workers under both the LCP and the SAWP are virtually bound to a single employer during their stay in the country. If a worker wishes to change employers, it is necessary to obtain a new work permit (a process which can take months). Working without a permit can be grounds for deportation, and so many migrant workers find themselves in a situation similar to indenture. "Aside from the fact that the stipulations of their labour contract are rarely enforced on their behalf, migrant domestic workers - like all migrant workers - face enormous disadvantages because they are indentured to their employers" (Sharma: 105). This problem is exacerbated in the case of LCP participants who are bound to live in their employers' homes, albeit in a private room in the house 
(according to federal law) (Stasiulis and Bakan). SAWP workers may face a similar lack of privacy living in employer-provided housing on the farm (UFCW, 2004).

\section{Conclusion}

The SAWP and the LCP are programs which respond to varying degrees to the needs of both employers and workers. Designed as they are by the Canadian state, and mainly in the interest of alleviating labour shortages in specific industries, the programs both impose restrictions on workers' labour mobility while in Canada. A number of motivations drive workers who choose to come to Canada to work. Poverty in their home countries is often linked to structural adjustment and other macroeconomic policies initiated by the IMF/World Bank, or under international trade agreements such as the NAFTA. As a result, people who in earlier times would not have had to travel for work, instead relying on employment close to home or even on their own farms to feed their families - now must make the trek to a distant country that is partly responsible for their need to move in the first place.

Of significant interest is the way in which migrants' family relationships are managed and even marshalled to the aid of less-wealthy, labour-sending countries. Migrants who work to earn a wage and send it home from Canada and other wealthy countries actually contribute more as individual workers to their home economies than foreign direct investment and foreign aid combined. Here a private, emotional relationship serves as the backbone for a very public state economic recovery program. In the process, migrant workers often labour in conditions of invisibility for the sake of their families. Their moral standing as social individuals and citizens in Canada suffers as a result of their being labelled as migrant workers (Sharma). 
In the next chapter I begin to examine this moral standing more closely, through the lens of transnational citizenship. Chapter three argues that citizenship is a useful concept for studying migrant work in Canada, and that transnational citizenship can be a powerful conceptual tool both for understanding international migration for work and for advocating for the rights of workers. It concludes that migrant workers within the SAWP and the LCP experience transnational citizenship in a gendered manner which differs from the citizenship of other workers in Canada. While both programs have strong similarities, the most striking difference between them is the way in which farm work is masculinized, while care work is feminized according to tradition. The implications of this for migrant workers in Canada are explored below. 


\section{Transnational Citizens, Interdependency and the Public-Private Divide}

\section{Introduction}

There are various frames in which to cast the experiences of workers who engage in migrant work programs in Canada. Below I use citizenship as a conceptual tool for understanding how migration for work is experienced by workers involved in the LCP and the SAWP. My current purpose is to provide a critical introduction to transnational citizenship as a concept for analysis. I include two elements in the analysis of migrant workers' citizenship which have been predominantly the concerns of feminist scholars: the distinction between public and private realms and the contrast between interdependency and liberal autonomy. A critical understanding of transnational citizenship under the above conditions can make it easier to highlight possible strategies of resistance and advocacy among migrant workers and their allies, which might otherwise appear insignificant in the broader political context. These opportunities are discussed in greater detail in Chapter Four.

Nikolas Rose writes that "concepts are more important for what they do than what they mean. The value of concepts lies in the way in which they are able to provide purchase for critical thought upon particular problems in the present." (Rose, 1999: 9). Concepts are analytical tools which help us to frame social facts coherently. The actual usefulness of transnational citizenship as a tool of this kind depends on how well it can be used to frame social phenomena such as work and migration. One possible difficulty associated with transnational citizenship is the potential for 'conceptual stretching' (Fox, 2005). Conceptual stretching occurs when a concept is made to include so many different and disparate social facts that in the end it loses its distinct meaning and ceases to be of 
use as a framing tool. In the present case, this danger stems from the fact that citizenship is itself a broad concept which has undergone changes in meaning over literally thousands of years. Nevertheless, in spite of its many possible interpretations, citizenship, beyond its juridical meaning, remains a powerful idea in law and popular discourse (Hall and Held). Below I connect my discussion of migrant citizenship to a framework inspired by the limits of Canadian state immigration law.

\section{Legal Status and Freedom of Contract}

Citizenship can be understood as a form of juridical status, as well as a constant process of negotiation for rights and respect (Stasiulis and Bakan). Both understandings are of importance to the present discussion. The first, legal status, may appear on the surface to be of most direct relevance to migrant workers in Canada. In a sense, this is true. The legal status of workers governs their employment relationship, as well as the other social relationships which are open to them while on a work contract. Citizenship as legal status is an intriguing place to start also because of the way it is defined in Canadian legislation, and what this may tell us about the exclusionary aspects of citizenship as a social concept (Baines and Sharma).

The legislative definition of citizenship in Canada does little to explain what citizenship is, but it does serve one important purpose from the perspective of the Canadian state. The definition of 'citizen' in the Citizenship Act reads as follows:

2 (1) In this Act,

$[\ldots]$

"citizen" means a Canadian citizen;

“citizenship" means Canadian citizenship; $[\ldots]$ 
In other words, from the point of view of the legislator, a citizen is one of 'our' citizens, and citizenship means 'our' citizenship - but what that citizenship might mean outside the four corners of the legislation is left to the imagination of its interpreter. Rather than truly defining citizenship, the Canadian Citizenship Act tells us only where and when we might find 'it', and who its possessors might be. This lends support to those who suggest that citizenship is an exclusionary concept, since it enables the formation of an artificial boundary around the citizenship community (Baines and Sharma; Sharma; Stasiulis and Bakan). In the context of migrant work in Canada, it is the ability of the Canadian government to limit who may and may not enter the country which makes it possible for the state to enforce labour contracts among temporary migrant workers (Satzewich).

Satzewich (1991) explains the history of migrant and immigrant farm labour in Canada, including the incorporation of Displaced Persons from World War II Europe from 1947 to 1954 . His description offers an instructive example. In this early immigrant work program, ostensibly designed to assist individuals who had lost everything in the war, one can see how the ability of state governments to use juridical citizenship as a means of regulation and outright exclusion served to supply labour to farmers at peak times of the growing season. The scheme was fairly simple. A Displaced Person was admitted to Canada to work under contract in the farming industry. Upon finishing a full year of work for a farmer, the individual was then free to circulate in the labour market and to take up residence in Canada (Satzewich), a less-onerous immigration process than that which currently faces LCP participants.

However, the program ran into difficulties. First, some workers failed to finish their twelve-month work terms, yet remained in Canada. They were threatened with 
deportation, although this was not a universally applied response (Satzewich). The deportation threat used in the post-war era highlights the extent to which a worker's contract of employment and his or her legal citizenship status have been linked since before the advent of 'globalization,' the LCP, or the SAWP. Commenting on a statement by the Deputy Minister of Labour condemning farm workers who quit their jobs before the end of the work term, Satzewich writes:

First, [the statement] defined Canada as a 'free' country, or as a country with free institutions. One of the features of this freedom was that labour was able to circulate in the market [...]. Second, migration was defined not simply as a method by which the accumulation of capital was facilitated, but rather as an aspect of nation state formation. Movements of immigrants involved people who were eventually to become citizens of the nation. Third, keeping a contract was an obligation of citizens of a free country. This was important even though the contract contradicted the idea of freedom, and even though it constituted the immigrant as a class of unfree wage labour. [...] the Displaced Persons were defined as having entered their contracts under their own free will and in the absence of external constraint (1991: 95-96, emphasis added).

Another way to understand the above response to what in contract law circles would be called an 'efficient breach' by immigrant farm workers, is as an offence against the graduated citizenship status accorded Displaced Persons admitted to Canada following the war. It is important to remember that with the end of the Second World War, Canada lost its supply of detainee-labourers of Japanese and German ancestry (Satzewich). These workers, already present on Canadian soil before the start of the war, saw their own citizenship status erode as relations between Canada and the country of their birth deteriorated - until they were suitably marginalized to be considered appropriate for employment in farm labour. Following the Second World War, other workers were needed to make up the shortfall. 
The above Deputy Minister's statement, which was part of the public record at the time, held out the possibility of full citizenship for workers who fulfilled their contractual obligation to the employer, and by extension to Canada. However, to make this bargain in the first place, workers had to have the capacity to contract in Canada. As such, before even beginning their work terms, and even though Displaced Persons were arguably unfree under this program, the state acknowledged that they had at least one of T. H. Marshall's three aspects of citizenship: civil citizenship, including the freedom to contract (Marshall). The understanding was that wise use of this citizenship right would lead to full legal status in time. The Canadian state was able to use its ability to limit access to citizenship status as a way of enforcing what in other circumstances would have been a private contract of employment, however this could only be done based on the prior acknowledgement of a limited, but present form of citizenship (Marshall).

The second difficulty which Canada encountered with respect to the Displaced Persons involved in farm labour from 1947-54 was that many workers left their farm employment as soon as they were legally permitted to do so. This meant that a farm worker hired in the summertime would walk off the job the following summer, regardless of what stage of the growing season was upon him (Satzewich). In the words of one commentator at the time:

This appears to be particularly true in the case of those men whose employers have sponsored the entry to Canada of their wives and families, but who promptly leave their employers at the end of their twelve-month period, regardless of the inconvenience it may cause the employers during the harvest time (Satzewich, 97).

Once free mobility was granted to a worker, especially where family was involved, it made little sense to remain on the farm when better work was to be found elsewhere. 
Upon lifting the limits it had placed on farm workers' citizenship within Canada, the state instantly lost much of its coercive power over these workers. Of course it could simply alter the program, however political concerns at the time made this inconvenient (Satzewich).

A current parallel can be found in the LCP, which today allows domestic workers to apply for residency after their two-year term in Canada. Upon receiving their papers, many live-in caregivers leave homecare employment, favouring other work which does not demand that one live in the employer's home. There is consequently a constant shortage in the industry, though Sharma (2006) rightly argues that were working conditions in supposedly migrant-dependent industries to improve, this would no longer be the case. Sharma argues that there is a shortage in Canada not of labour per se, but of easily exploitable workers, which migrant work programs help to attract (2006).

What differs today from the Displaced Persons program is that until migrant workers under the LCP have completed their 24-month work terms and applied successfully for status, they are unable to bring their families to be with them in Canada. Likewise, SAWP workers are unable to have family members accompany them during a work term. As if the products of earlier experience, both the LCP and the SAWP limit the possible 'distraction' from work posed by family connections. Workers may be in Canada in order to support their families, however while they are there any further involvement in the form of visits from relatives is legally impossible. One could argue that from the perspective of the exclusionary state, the present-day "permanently temporary" status of SAWP workers (Sharma) represents the perfection of the restrictedcitizenship regime begun shortly after the Second World War. It is also highly traumatic 
for migrant workers, who complain less about their working conditions under the SAWP than about the pain of being separated from their families for such a long time period every year (Gutierrez; Grez).

By excluding workers from full citizenship rights, the state has used its power over the restriction of legal citizenship status in such a way that the private contract between employer and worker is enforced more effectively (from the employer's perspective) and more coercively (from the worker's perspective) than could ever be expected among people who are free to move within the Canadian labour market (Sharma). The fact that SAWP and LCP participants alike have family waiting for them in the country of origin completes the picture. However, the use of citizenship status as a means of controlling worker mobility is based on a prior citizenship right, a private right held by the worker in liberal contract theory, exercised in this case across borders. Migrating workers begin their journey to Canada as transnational citizens in the civic sense, albeit without the same freedoms as full citizens of the Canadian state.

\section{Interdependency and Exclusion/Inclusion}

A complication for the state power to limit citizenship arises when we consider the legally sanctioned routes to obtaining legal citizenship status, of which there are three. One means of obtaining status requires a citizenship examination, an oath of loyalty and a complex application process (s.3, Citizenship Act). However, the other two require a minimum of effort on the part of the citizen: one must be either born of a Canadian parent, or on Canadian territory.

Both jus sanguini and jus soli citizenship can pose a problem for a state which wishes to maintain control over citizenship status as a means of supplying labour to 
needy farmers and busy families. If a migrant worker reproduces with a Canadian citizen, or gives birth to a child on Canadian soil, this may blur the citizen-non citizen distinction which is essential to the proper functioning of temporary migrant work programs.

Although she was not a participant in the LCP or the SAWP, the story of Mavis Baker's appeal to the Supreme Court of Canada is instructive in this regard (Baker, 1999;

Stasiulis and Bakan). Ms. Baker came to Canada as a visitor in 1981, but stayed on for eleven years after her visa expired. Without state permission or immigration status, Ms. Baker supported herself and her children as a domestic worker during that time. She also gave birth to four children while in Canada.

Ms. Baker was ordered deported in 1992, however she applied for an exception to the order based on humanitarian and compassionate grounds. In denying her application, the Citizenship and Immigration Canada officer emphasized in his notes to the department the following transgression against government control over citizenship: "She has FOUR CHILDREN IN JAMAICA AND ANOTHER FOUR BORN HERE”' (Baker, 1999: par. 5, emphasis in original). He concluded that because Ms. Baker was diagnosed with mental illness and on welfare at the time of her immigration appeal she would "be a tremendous strain on our social welfare systems for (probably) the rest of her life [...]. I am of the opinion that Canada can no longer afford this type of generosity," he concluded (Baker, 1999: par. 5).

The comments of the immigration officer regarding Ms. Baker's likely need for social welfare ignore the fact that her children had the potential to one day work and support her, making welfare only a temporary measure. Also ignored was the potential impact of separation from their mother or deportation to another country on the ability of 
her youngest children to one day support themselves. Baker (1999) placed the issue of 'illegal' immigration to Canada in the public spotlight, including the political question of how much control Canada could (or should) exercise over the boundaries of membership. This pre-2001 debate has significance for present-day readers: even in the absence of pressing security concerns, political conflict over border control and juridical citizenship was heightened by the possibility of 'unauthorized production' of Canadian citizens on national territory. The immigration officer's concerns (and prejudices) were reflected in the argument of Mr. Leon E. Benoit, Member of Parliament for Lakeland (Canadian Alliance) before the House of Commons shortly after the Supreme Court decision in Baker (Benoit, 2000). Mr. Benoit moved (unsuccessfully) that jus soli Canadian citizenship be abolished, with citizenship only to be given to children born of Canadian citizens or landed immigrants. His motion was in part a response to fears that:

More people will come to our country illegally, have children and then use the argument that because they have a child who is a Canadian citizen they should be allowed to stay. I do not think anyone would deny that argument has been used for being allowed to stay in the country when people otherwise would not be allowed to stay. It is a problem (Benoit, 2000).

The above potential disruption of state control over citizenship puts the following comments by Preibich on migrant work in Canada into proper context:

A further aspect of temporary employment authorization structuring labour relations is workers' civil status upon recruitment and their entry as single applicants. Preference in recruitment has been biased historically toward married/cohabitating workers or single workers with dependents in order to deter workers from attempting to secure permanent residency through marriage or seeking to remain in Canada illegally. This characteristic of the SAWP treats workers as members of family on the one hand, yet single applicants on the other, as they are unable to bring-or visit_-their families during their course of work in Canada. The fact that workers have limited social commitments in Canada is one of the reasons they are particularly valuable to employers [...] (p. 5, emphasis added). 
The Supreme Court of Canada in 1999 did consider the potential impact of the officer's decision on the lives of Ms. Baker's Canadian citizen children (Stasiulis and Bakan). What allowed Ms. Baker to avoid deportation in the end was the dependence of her children on her. The Court recognized that children and parents form an interdependent relationship which should be protected in Canadian law. However, the Federal Court trial decision in the case had stated almost the opposite (Baker, 1995). The Federal Court judge held that " $[\ldots]$ the act of deporting parents is not a government action with respect to the children [...] whether the children stay in Canada is a private decision to be made in the best interests of the children" (Baker, 1995: par. 33).

The Baker 1995 trial decision stands as an appropriate representative sample of liberal reasoning when it comes to dealing with citizenship and the individual. When citizenship is considered on a strictly individual basis, assuming an autonomous person as its bearer, it is relatively simple to separate one person from the other and exclude those who do not 'belong' in Canada. Martha Fineman (2002; 2004) argues that one of the founding myths of liberal societies is that of the complete autonomy of the members of those societies. The liberal individual is considered a legal subject in isolation, whose ties to family have no bearing on his or her rights in the public sphere. The assumption is also made that liberal citizenship can mean only that which is experienced by abled individuals of majority age, who require no care on the part of others (Fineman, 2004). Of course all citizens pass through stages in which they are dependent on others, or in which others are dependent on them. As the Supreme Court recognized in Baker, in reality citizens are not fully autonomous but are instead constituted and supported by relationships of interdependence (Fineman, 2004). The migrant work contract under both 
the SAWP and the LCP may not mention the family bonds which motivate workers to join each program, but all involved know that the worker is involved in relationships beyond the individually-based contractual arrangement with the employer. Neither contract provides for a plan in the event that a female worker becomes pregnant while in Canada, or that a worker of either gender develops a loving relationship with a Canadian citizen during the work term. Within the context of migrant work in Canada, such things are generally discouraged, if they are considered at all (Preibich).

A word must also be devoted to the reverse of the situation in Baker: the cases where workers find themselves potentially dependent on others while in Canada. This, too disrupts the contract of employment and Canada's control over belonging under both programs, but it is perhaps most strongly expressed in the reaction to agricultural migrant workers who fall ill on the job.

The life of a Canadian agriculture worker is difficult and dangerous. "In Canada, farm-related deaths per 100,000 are nearly four times higher than the rate for all industries combined" (London Free Press, cited in UFCW, 2004: 14). In 2002 for example, Ned Peart, a tobacco farm worker from Jamaica was killed in Ontario when a 450 kilogram bin fell on him, crushing him. The province of Ontario has yet to launch a coroner's inquest into the accident, despite requests from Peart's family and local groups (Richmond). Other injuries are commonplace: "Broken bones, eye injuries, sprains, strains, muscle pulls, back problems and rashes fill the annual reports of the United Food and Commercial Workers Union (UFCW), which runs migrant centres in Leamington, Simcoe, Bradford and Virgil, near Niagara Falls" (Richmond). While these injuries are potential risks for all workers in the agriculture industry, the element of citizenship 
complicates matters significantly when it comes to dealing with workplace injuries or deaths. Worker knowledge of legal rights may be incomplete, and inadequate knowledge of English or French may prevent some migrant workers from establishing the necessary social contacts to educate themselves further (Basok, 2002; Preibich). Moreover, for a migrant worker the threat of repatriation lingers in the background, discouraging many from reporting even serious injuries. Most significantly, where a migrant worker shows signs of possibly becoming dependent on institutional health care while in Canada, the easiest and most logical solution among employers is to send the worker home rather than allowing that dependency to take root and keep the worker in the country (Justicia; Grez).

On the surface, the SAWP and LCP frameworks begin with the power of the Canadian state to define citizenship status and grant or withhold it as needed for the sake of present-day Canadian economic actors. However, this power is influenced and disturbed by relationships which are generally thought to be beyond the employment contract and outside the scope of liberal citizenship.

\section{Citizenship, Public and Private}

As indicated above, the programs themselves are based on a strict demarcation between the private realm (the family, relationships with close relatives and friends) and the public arena (the workplace, including the rural community where one is employed). While families in the state of origin are often the motivation behind workers' journeys to Canada, they are not allowed to accompany the worker or distract him or her from their occupation. However, the effect of the distinction between private and public on citizenship practices under the SAWP and the LCP is even stronger when we consider its effect on the daily working lives of participants. 
Gavison (1992) writes of feminist critiques of the distinction between public and private spheres. She explains that some feminists oppose the distinction entirely, believing that because 'the personal is political,' the private realm does not in fact exist. On the other hand, Gavison explains that although the distinction is applied in harmful ways, by sanctioning the abuse of female partners for example, this misapplication should not lead us to discard the distinction as a theoretical tool. Even on the level of political activism, it is arguable that some degree of private life is absolutely necessary in order to foster the conditions necessary for full public participation, and full citizenship.

In the first chapter of the thesis, I acknowledged how different child and elder care appears as an occupation from agricultural work. At the same time, I mentioned that both industries are among the least attractive to workers in Canada. Another aspect which is linked to this low status is the impact of notions of private/public, closed/open, and hidden/exposed in each industry. Farm workers and live-in caregivers share an invisibility which makes migrant workers more vulnerable to employer abuses than their citizen counterparts (Stasiulis and Bakan; Sharma; Basok, 2002). This invisibility is shared not only because the workers in question come to Canada from another country, though this is a factor. The hidden, private injustices of work under the LCP and the SAWP are in part a result of the fact that both live-in caregiving work and farm labour are the traditional work of the marginalized. Today, these industries have a marginalizing influence on workers.

To be marginalized is to be pushed out of the public realm and away from full enjoyment of social life. To be marginalized is to be a second-class citizen. Added to the already-mentioned difficulties of workers under the SAWP is the social exclusion which 
many migrant agricultural workers experience when working in Canada. Migrant workers are not always well integrated into communities where they work - rather, they are often seen as part of the scenery, a cut-out figure on a bicycle (Bauder and Corbin), or a face in the crowd in front of the supermarket on Friday nights (Basok, 2002). Scholars and activists have sought to draw public attention to the significant barriers of language, socioeconomic status and prejudice which can prevent agricultural migrant workers from participating fully in the social life of farming communities (Basok, 2002, 2004; Lowry; Preibisch; Lee). However, the social exclusion of agricultural workers is not a new phenomenon. Rather, it has persisted ever since wage labourers became necessary on expanding farms in Canada (Satzewich).

Historically, recruitment practices for farm labour have not paralleled those of other industries in which workers were in high demand. Farm worker recruitment has been marked by racialization and the targeting of vulnerable social groups for coercion. Rather than offering incentives which would make farm work more attractive than other available work opportunities, state policy has in the past been to fill vacant agriculture jobs with members of marginalized groups: "Children, Aboriginal peoples, the urban unemployed, and convict labour in Quebec were all recruited or targeted to meet the labour demand. During the Second World War, the federal government also supplied to growers German prisoners of war, Japanese Canadian internees, and conscientious objectors..." (Verma). Agricultural employment has long been the work of second-class, or non-citizens.

Government-sanctioned employment of socially excluded people in agriculture continues today, with recent examples of employment insurance recipients and social 
assistance clients being either asked or obligated to work on farms in return for their benefits (Basok, 2002; Bauder and Corbin). This is reminiscent of T. H. Marshall's commentary on the Poor Law, a system of poverty 'relief' in force in England until 1918 (Marshall). In his essay Citizenship and Social Class, Marshall wrote that

The Poor Law treated the claims of the poor, not as an integral part of the rights of the citizen, but as an alternative to them - as claims which could be met only if the claimants ceased to be citizens in any true sense of the word. [...] The stigma which clung to poor relief expressed the deep feelings of a people who understood that those who accepted relief must cross the road that separated the community of citizens from the outcast company of the destitute (Marshall, 83).

A policy of "farmfare" (work-for-welfare in agriculture) was considered by the Ontario provincial government in 1999, as a means of 'supplying' labour to agricultural employers. However, the proposal was soon dropped - amid arguments in the mass media that farm work was demeaning, involved few skills and was too strenuous for many Ontario residents (Bauder and Corbin).

As demonstrated by the opposition to 'farmfare' in Ontario, resistance has developed against the use of openly coerced labour on farms. At the same time however, Bauder and Corbin (2002) have found a marked tendency in the Canadian contemporary mainstream press to characterize migrant workers as 'naturally' or biologically better suited to the hard work which farming demands. "In conjunction with the depiction of foreign workers as better suited labour for fruit picking than Canadians, migrants are often portrayed as enjoying this type of work and the lifestyle that comes with it" (Bauder and Corbin, 11). Workers under the SAWP compete for the privilege of working at a job which is invisible to most urban Canadians, and which rural Canadians disdain. As such, the SAWP reinforces the historically held view that despite its importance for a secure 
food supply, agricultural work is largely the work of marginalized people. This stands in clear contradiction to popular notions of cooperative work on the 'family farm.'

At the same time, seldom does the mainstream public in Canada actually see migrant agricultural workers on film or in the news, nor do migrant farm workers frequently write letters to the editor or speak out in schools about their lives (though this does occur). The ability of migrant workers to experience full citizenship in the social and political sense is hampered by the fact that they are often confined to their employer's land, far from any amenities (Lee). In the National Film Board documentary El Contrato, the power of employers to take advantage of the privacy of the 'family farm' is made evident. After filming a meeting at which SAWP workers complain of physical abuse by a supervisor and substandard working conditions, the film crew is told to leave the farm and never come back (Lee). The family farm (often a large business) on which a migrant agricultural worker lives and works is a private domain from the point of view of the employer. Living on the farm or in employer-supplied housing, migrant agricultural workers have less access to traditional public spaces both real and metaphorical, in which to exercise their limited citizenship.

The marginalization of workers under the LCP is also linked to their invisibility (Blackett). A live-in caregiver is confined to her employer's private home for most of her working (and waking) hours. A worker within the LCP literally must live at her workplace. Caregiving work, which is isolating even for citizen family members, can be even more so for a person living in a new country. The private workplace of the live-in caregiver not only serves to isolate and marginalize, but it also makes the application and enforcement of public labour and health legislation difficult to accomplish. On one level, 
by hiring a live-in caregiver, employers come under the jurisdiction of labour boards and even (in some cases) workplace safety and compensation regimes. They are responsible for making the same deductions at source which any business owner must make on behalf of employees. They are subject to the same prohibitions on unfair labour practices, human rights legislation and other laws. Hiring a live-in caregiver through a private work contract should in a legal sense make a public place of the employer's home. However, there are reasons why this does not occur.

Chief among these reasons is the fact that most labour regulation schemes are complaint-driven. The result, familiar to employment lawyers, is a system whereby employees are made responsible for first discovering that they have a rights-based claim, and then successfully marshalling the courage and resources necessary to pursue that claim. In the words of the guidebook supplied to live-in caregivers entering Canada, "It is your responsibility to know the laws that apply to you and to look after your own interests." $" 5$ The same is implied in the comment of Alain Major, a Quebec Labour Standards Commission representative who was asked to comment on the case of a wrongfully dismissed live-in caregiver in 2003 . The pregnant worker had been fired after she refused to go through with an abortion which her employers had scheduled for her without her consent (Montgomery). Asked about the low number of complaints filed by live-in caregivers in Quebec, Major replies that "[t]hey're vulnerable and that makes them afraid to file a complaint" (Montgomery).

As such, although live-in caregivers (and agricultural workers) have a civil right to have their contracts enforced by law, the combination of a rights-based, complaint-

\footnotetext{
5 "How are Contracts Enforced?" in The Live In Caregiver Program, Citizenship and Immigration Canada publication, url: http://www.cic.gc.ca/english/pub/caregiver/caregiver-2.html\#9.
} 
driven enforcement system with the private isolation of workers while on the job has a negative impact on this aspect of their civil citizenship while in Canada.

In contrast to the invisibility experienced by workers in relation to the broader Canadian citizenry, workers under both the LCP and the SAWP are highly visible to their employers. In fact, whereas the private nature of their workplaces serves to hide them from the public (in their employers' favour), the distinction between public and private works in a very different fashion within the place of work to make the establishment of a private life difficult for many workers. The live-in requirement under the LCP makes some caregivers feel that no matter what they are doing 'at home' they are at all times also 'at work'. A live-in caregiver has a right to her own room with a lock on the door. However, this rule is 1) not always observed by employers, and 2) not enough to provide a caregiver with protection of her private life while at work during the week.

Workers can have their privacy limited to a great degree by employers. In more serious cases employers may even try to interfere in the most private health matters of 'their' employees. The 2003 case of the pregnant live-in caregiver cited above is one such extreme example. The UFCW has documented similar, if less-shocking violations of worker privacy by employers involved in the SAWP:

In many cases, workers have complained about lack of personal freedom and privacy during non-work hours. Workers indicated that they were afforded little privacy while making phone calls because their employer shared the phone line and was believed to be monitoring their conversations. Others reported that their mail was opened by the employer.

In one case, a female employer insisted that she be present during a medical examination of a male migrant worker, even though he was clearly uncomfortable with the situation. This intrusion occurred at a medical follow-up examination after the worker decided to consult a doctor of his choosing. The reason for her insistence was that she objected to the doctor and the resulting determination that the injury was work-related and therefore compensable (UFCW, 2004: 12). 
The above report indicates that two important aspects of workers' citizenship are limited by the fact that they live and work in the same place, with the same employer. First, the establishment of a personal social life and the social connections that make public participation accessible are limited by the inability of workers to have a private telephone conversation or to receive mail untampered. Second, the worker's exercise of his right to obtain compensation for on-the-job injury (a social and contractual right) is limited by the employer's ability to sit in on medical examinations regardless of the worker's feelings on the matter.

\section{Conclusion}

When we consider citizenship (civic, political and social) as experienced by workers under both the LCP and the SAWP with the distinctions between private and public, and interdependency versus autonomy in mind, several conclusions should be made clear. First, in a legal system based on a liberal conception of the autonomous individual citizen, relations of interdependency have the potential to disrupt citizenship law, and make for difficult cases in the courts as well. The ability of workers to foster affective relationships in Canada poses a problem for immigration officials and employers alike - whether or not such relationships result in Canadian offspring. Second, because migrant workers entering Canada under the LCP and the SAWP are assumed to be autonomous individuals (despite their reasons for joining the programs), any threat to their self-reliance and ability to work while in Canada is seen as an impediment to continuation in the program and may lead to repatriation. Third, the private ownership of places of work allows for the isolation and marginalization of migrant workers under both programs. Finally, and perhaps most damaging, while hidden from public view, 
workers may be denied a sense of private life that is separate from their place of work. Once they enter Canada, LCP and SAWP participants are subject to the preferences of their employers when it comes to the degree of private space available to them. For some unlucky people, the public/private divide runs right along the border between Canada and their home state. In this respect the transnational citizenship which workers establish in coming to this country is seriously limited upon their arrival.

At the same time, acknowledgement of these aspects of worker citizenship while in Canada opens the possibility for a discussion of possible strategies for improving migrant workers' living and working conditions while in the country. It is to these opportunities which I turn next. 


\section{Gendered Citizenship, Worker Resistance and Legal Change}

\section{Introduction}

In the previous chapter I argued that migrant workers become transnational citizens even before arriving in Canada. However, this citizenship does not translate into free conditions of work. Below, I use a gendered understanding of citizenship as a tool of analysis. Based on the arguments made by the courts and parties in several cases, I argue that a gendered understanding of citizenship may be incorporated into successful strategies of worker resistance and legal change.

In the cases examined, the role of workers' allies is significant. Three of the cases were brought forward by the United Food and Commercial Workers Canada (UFCW), in cooperation with groups of migrant agricultural workers. The UFCW has a long history of working with SAWP participants, representing workers in the courts and certifying agricultural unions in jurisdictions where this is permitted (Fraser v. Canada, 2005). The cases examined in this chapter include Fraser $v$. Canada (2005), in which the UFCW began litigation to win access to Employment Insurance benefits among migrant agricultural workers. This matter is still before the courts. The two other UFCW cases are the Supreme Court of Canada decision in Dunmore (2001) and its aftermath, chronicled in Fraser v. Ontario (2006). Both deal with the right of agricultural workers to join unions in Ontario. Although the Supreme Court in Dunmore pointed out that its decision did not apply to migrant farm workers directly (par. 103), in the ensuing years it has become evident that the result of the case had effects for SAWP participants in their capacity as workers in the farming industry. For example, Ontario recently included agricultural workers in its occupational health and safety legislation. This measure covers 
migrant and resident agricultural workers alike. As well, migrant agricultural workers in other jurisdictions have made efforts toward joining unions and bargaining collectively in the time since Dunmore was decided (Fraser v. Canada).

All of the above cases deal with citizenship practices of migrant workers: the joining of associations and the obtaining of social benefits from the state. An analysis of the above case law from the perspective of gendered citizenship exposes how employer manipulation of the public-private distinction, and the denial of relations of interdependence can result in the further marginalization of workers. In doing so, it highlights potential avenues for worker resistance and change. To argue the above in this chapter, I build on a feminist critique of citizenship put forward by Donna Baines and Nandita Sharma (2002).

\section{A Critique of Citizenship}

Baines and Sharma provide a clear argument against citizenship as a progressive social policy concept for activists and academics to use when envisioning better circumstances for migrant workers living through difficult times. They argue against using citizenship as a template for constructing goals for migrant progressive politics. Borrowing from Catrina Brown, the authors make the important point that when we use "[...] purportedly liberatory concepts in social change projects, what we think we're doing isn't always what we are doing" (76). They argue that citizenship is a concept loaded with 'dead, white male baggage' and as such is of little use to progressive movements.

It is important at this point to distinguish between using citizenship as a concept for descriptive analysis and employing it as a basis for normative claims to justice and 
equality. In the normative sense, a person who speaks as a citizen may do so in order to demand recognition of an equality as yet not realized. An illustration of this point is provided in the reaction of an Ontario lawyer to the acts of a "small army' of seventyfive" Ku Klux Klan members in the town of Oakville in 1930:

The Klansmen had learned that Johnson, 'a Negro,' was living with a 'white girl' named Isabel Jones. Their intent was to discipline the racially upstart Ira Johnson and put an end to the mixed-race liaison. [...] The costumed marauders surrounded the house, and turned Ira Johnson and his relatives out in the front yard. Then they nailed a large cross to a post in front of the door and set it on fire. (Backhouse, 173-4).

While the 'citizens of Oakville' were reportedly satisfied with the incident (Backhouse),

E. Lionel Cross, a Black lawyer practicing in Toronto spoke with the London Free Press, contrary to the prevailing view:

I call the doings at Oakville last evening an outrage. As a British citizen, I have believed the rule of the law should always prevail. [A man] is free to choose what companions he cares to have. When anybody under the guise of patriotism or any other 'ism' trespasses on the right of any man, no matter who he may be or of what race, it should be the duty of all law-abiding citizens to denounce any such action (qtd. in Backhouse, 176-177).

In protesting what today would be defined as a hate crime, Cross positioned himself as a member of the British citizenry. In doing so he made a demand for equality in the name of citizenship which he insisted belonged as much to him as to those who attacked Ira Johnson. It is worth noting that Cross made an appeal to British citizenship, arguably seeking to use a form of transnational citizenship to promote social equality within Canada.

Baines and Sharma caution against this approach to citizenship, which depends for equality upon defining oneself within the parameters of one group of same citizens, instead of recognizing plural identities. However, in this chapter I make no normative 
claim to citizenship on behalf of migrating workers. Instead I argue that a gendered perspective on citizenship, which recognizes that traditionally the home has been considered a non-citizen place (Baines and Sharma), provides a useful tool with which to understand recent efforts by migrants and their allies to improve their working and living conditions within Canada.

\section{Interdependency, Recognition and Citizenship: Fraser v. Canada (2005)}

While there are many angles from which to approach this assessment of the worth of citizenship as a concept, I would like to focus in the present section on the gendered nature of citizenship in historical context. The statements of T.H. Marshall (1963) with respect to the development of citizenship in liberal democracies are of use in understanding the belief of some in the power of citizenship as a normative force, but also as a means of understanding how societies function and change. Marshall wrote of citizenship not as a single type of status, but as a series of developments in the history of his society. The evolution of citizenship could be traced from its most basic form - what he termed 'civil' citizenship, through the development of political and finally social citizenship. The first of the three involved the most basic of civil rights. As noted in Chapter Two, these include the right to freedom of contract - a right which migrating workers exercise on a transnational basis when they first enter a work contract with a Canadian employer. In this sense at least, migrant workers are transnational citizens from the beginning stage of their journey.

Marshall's second form, political citizenship, involves the right to take part in the political life of one's society. This includes electoral voting and broader kinds of political participation. Unions have been recognized in the courts as having a role to play in the 
promotion of political citizenship among members. The role of unions in the political system of Canada was a subject of argument in the Supreme Court of Canada decision Lavigne (1991). Examining the connection between collective bargaining, the Rand formula and union political activity in the case of a Canadian resident, Wilson J. explained that unions are not limited in their activities to purely economic functions:

Unions' decisions to involve themselves in politics by supporting particular causes, candidates or parties, stem from a recognition of the expansive character of the interests of labour and a perception of collective bargaining as a process which is meant to foster more than mere economic gain for workers. From involvement in union locals through to participation in the larger activities of the union movement the current collective bargaining regime enhances not only the economic interests of labour but also the interest of working people in preserving some dignity in their working lives (Lavigne).

While the above case did not involve migrating workers, the importance of political citizenship for working people, and the need for institutions to strengthen this citizenship outside the workplace is clearly implied.

Third and finally, Marshall posited social citizenship as a desirable end stage in the development of citizenship in liberal societies. This included the right to a minimum standard of living. Social citizenship is demonstrated in the availability of benefits such as Employment Insurance, housing subsidies, education support and other measures. Baines and Sharma rightly point out that the civil, political and even social citizenship rights advocated by T. H. Marshall and other social theorists of his time were mainly held by white men of property until fairly recently in European history (see also Stasiulis and Bakan). Only recently have women achieved the right to vote and begun to claim a greater part in the political life of their home states (Baines and Sharma). Meanwhile, in supranational organizations such as the United Nations, women are still far from holding 
$50 \%$ of executive positions, being instead relegated mainly to clerical and middlemanagement work (Lewis).

The above caution about citizenship as a concept is interesting for what it says about the link between gender and one's ability to obtain the rights of social citizenship in the present as well. Baines and Sharma argue that social citizenship "still is, integrally based on heterosexual women and men occupying very separate spheres in society maintaining distinct relationships to dependency and independence" (80). They argue that programs such as Family Allowance were designed to compensate women (in meagre amount) for the work of mothering, while other forms of traditionally 'women's work' went unrewarded (81). Moreover, the Employment Insurance/Unemployment Insurance scheme is said to reinforce women's subordination by treating the homemaker and mother as a "mother-citizen rather than as a full citizen actively engaged in all parts of social and economic life" (82). At the same time, Baines and Sharma confirm that "citizenship is experienced very differently by women, people of color and those marginalized by state policies, region and location" (82).

The Ontario Superior Court case of Fraser v. Canada (2005) provides a significant illustration of the above argument. This is an application made by the United Food and Commercial Workers (UFCW) for permission to represent SAWP participants in a constitutional challenge to the Canadian Employment Insurance (EI) system. Migrant agricultural workers and live-in caregivers all take part in the EI system by paying premiums deducted from each paycheque. However, under the current EI regime unemployment benefits are only paid out to workers who are present in Canada and able to seek paid work. Because workers under the SAWP must leave Canada upon 
termination of their contracts, and are at any rate forbidden to work for any other employer while in Canada, they are in all but a few cases ineligible for EI benefits. In the case of LCP participants a similar exclusion is possible, as caregivers must be employed in order to keep their work permits. Without the work permit, which is tied to an individual employer, an unemployed live-in caregiver can apply for a two-month temporary work permit, after which time if she has no employment she can eventually be deported (CIC, Processing). Nevertheless, the structure of the LCP is such that workers are able to gain access to EI regular and special benefits in some cases (CIC, Processing).

The UFCW has been involved in organizing efforts among migrant agricultural workers since before Fraser v. Canada. This work has included the establishment of migrant support centres, travelling legal information programs and advocacy among consular officials, employers and in the courts (Fraser v. Canada). In this context, some minor victories have been won in the area of employment insurance benefits. When we consider the perspective of Baines and Sharma, it is significant that where migrant workers have received EI benefits, they have done so under an EI benefit plan designated for 'stay-at-home' family care providers (Fraser v. Canada). The Ontario Superior Court explains the statistical impact of this change:

Of approximately 54,000 SAWP workers who have paid premiums between 2002 and 2004 , the government estimates that 190 have been approved for [maternity or parental leave] benefits. In some cases, these benefits have amounted to as much as $\$ 8,500$ against only a few thousand dollars worth of gross pay. As of December 2004, a total of 303 active applications were on file. The UFCW claims that to its knowledge, no SAWP worker has ever received regular benefits, while only one has ever received sickness benefits. Before 2002, it claims, no evidence exists that any SAWP worker received benefits of any kind. The government has provided no evidence to the contrary (Fraser v. Canada, par. 8). 
As implied in the above quote, EI is divided into two sets of benefits: 'regular' and 'special' (Fraser v. Canada). This structure is anticipated by Baines and Sharma's critique of state child-rearing benefits. The 'regular' EI benefits, to which SAWP workers do not have access, are paid to unemployed individuals seeking a new job in the wage labour force. Regular benefits are the standard. However, outside the regular scheme there is a 'special' EI benefit. These payments cover parental and maternity leave, 'compassionate care' leave, and illness of workers. In other words, while the standard system is designed to protect autonomous wage earners, 'special' benefits are paid mainly to people who for reasons of interdependency and private relationships provide care work in the home.

From a feminist perspective, the EI benefit structure can be effectively critiqued as a social citizenship measure which separates traditionally 'women's work' from the broader workforce of autonomous citizens. In doing so, the EI system reflects the liberal assumption of worker independence outlined in the earlier chapters of this thesis. It may be true that for one group of state citizens (Canadian women), the 'special' benefit division described above represents the maintenance of subordinated citizenship through relations of interdependency with children and relatives. A person (still usually a woman) who provides care work in the family home receives parental leave benefits under a system which generally is accessed by people who are unable to find work at all. The same is true for maternity leave benefits, exclusively accessed by pregnant women, which fall under the same section of the Employment Insurance Act (1996) as parental leave. As such, care work is categorized as an extension of unemployment (a lack of work), and thereby contributes to the subordination of the caregiver. 
However, the experience of workers represented in Fraser v. Canada differs from above. Recall from Chapter Two that workers enter Canada alone, unable to bring family members with them. They are autonomous parties to the work contract, but are nevertheless motivated in their work by the need to support family members in their home states. This interdependency between workers and their families is ignored in the work contract and, aside from the SAWP selection process, in the migrant work programs themselves. The process whereby workers gain access to EI interrupts this denial. As indicated by the court, SAWP workers are effectively barred from receiving regular EI benefits, and have never received the special benefit for worker illness or injury. However, they have begun to win access to special benefits in cases of parental leave (available to men and women), and maternity leave (available to women only).

Through the EI special benefit, SAWP workers obtain institutional recognition for their relations of interdependency with family, as part of an advance toward full citizenship. This necessarily includes acknowledgment of the family responsibilities which motivate participants to work abroad. The cases in which parental benefits have been paid out to SAWP workers are few, however the function of these benefits for the workers is arguably different from that among Canadian-citizen recipients. For migrant workers, family benefits help to carve out a state-recognized space in which to affirm the existence of a private life beyond the workplace in Canada, and to make real financial gains in the process. It is a form of advocacy from which workers stand to make progress in terms of both money and recognition of their place as transnational citizens. 


\section{Mirror Image: The Family Wage and Live-In Caregiving}

One possible explanation for the above success of the family benefits strategy is the gendered nature of the work done under the SAWP, as well as the selection process for entry. Recall that the SAWP administrators prefer to admit only married men who have children to support in their country of origin. As such, workers are expected to fill the role of 'citizen breadwinner' (Baines and Sharma) in relation to their families 'back home'. The SAWP worker, like the LCP participant, is an earner of what in earlier times was conventionally understood as the 'family wage'.

Fraser $(1994 ; 1997)$ writes that the family wage (the single wage earned by one individual - usually a man - to support the whole family) has never completely reflected the reality of the lives of working people. Nevertheless, today a whole family of citizens in a wealthy nation living on one earner's wage, is an even less common occurrence than it was in the past. Fraser argues that state-run social programs such as welfare have not kept up with this reality, marginalizing single mothers who would otherwise be

considered full citizens. Their difficulty stems from being caught between the caregiving needs of their children and the requirement that they earn the family wage on their own (Fraser, 1994). This change may be true for state-citizen women in Canada, but under both the SAWP and the LCP the family wage is kept very much alive. As argued in Chapters Two and Three, workers come to Canada in large part to support families in their countries of origin. It is arguable that in this case the sending state and home community assume the role of what would have been 'home and hearth' in industrial North America. 
There is a relationship between the decline of the family wage in North America and the work of live-in caregivers (LCP workers) in particular. Fraser writes of the importance many feminists place on social innovations like caregiver allowances and universal childcare: programs designed to assist North American women who wish to enter the paid workforce. Stasiulis and Bakan (2005) argue convincingly that where the political will to fund universal childcare is absent, for upper-middle class families hiring a live-in caregiver becomes a good alternative. In this way, the labour of working women in the LCP contributes, albeit in small degree, to a further decline in the family wage among Canadian citizens. One could say that the gendered nature of LCP participants' citizenship as paid caregivers is implicated in the changing citizenship of Canadian women. If this is the case, then it can be anticipated that changes to the way in which the family wage of LCP workers is managed may meet with varying degrees of opposition among employers.

The conclusion that can be drawn from Fraser $v$. Canada and other efforts by migrants to obtain family-related benefits from the state is that we should avoid the easy assumption that because an aspect of citizenship can be interpreted as a setback for one group of citizens it will necessarily be the same for another. Recognizing that migrant workers are transnational citizens for the sake of justice means also recognizing that the conditions of their citizenship while in Canada will differ significantly from the conditions of Canadian citizens. What is exclusionary of Canadian citizen women may instead be emancipatory for non-citizen workers. Likewise, the emancipation of many Canadian citizen women can be linked to the continued exploitation of women from outside Canada. 


\section{The Family Home, the 'Family Farm': Dunmore (2001) and its Aftermath}

As argued in Chapter Three, migrant citizenship is governed by a stark division between the private, home environment of family and children in the state of origin and the public-yet-hidden work environment encountered in Canada. In the case of LCP and SAWP participants, the border may not only represent a dividing line in terms of economic status, but also represents a geographic and social division between the private and the public. Lack of access by migrant workers to a private sphere separate from their work in Canada makes the provision of social rights such as medical attention, education and parental benefits problematic even where rights to such things exist (Gutierrez; Basok, 2004).

The UFCW has documented cases where employers have invaded the privacy of SAWP workers by preventing them from making private phone calls and seeing a doctor alone (UFCW, 2004). In one case a female employer who disagreed with a male worker's choice of doctor ensured that she was present for his medical examination following a suspected workplace injury. The employer insisted on attending despite the worker's clear discomfort with the situation (UFCW, 2004). Tanya Basok has also documented the importance of social events and community integration outside working hours, to the exercise of SAWP workers' rights in Leamington, Ontario (Basok, 2004). For live-in caregivers, limitations on private life are also present. Under the LCP, caregivers must live in their employers' homes. They are not permitted to live elsewhere on penalty of losing the work permit. The program requires that employers give caregivers a room in their home with a lock on the door, however a lock will not prevent an unscrupulous employer from entering the worker's room without permission. Moreover, the rule is not 
always followed by employers in the program (Stasiulis and Bakan). Even where a private room is provided, workers under the LCP are 'always on call' in the homes of their employers, as explained earlier.

At the same time as LCP and SAWP workers must fight for the private life which so many Canadian citizens take for granted, the places where they earn a wage are defined as private, 'family' spheres in relation to the rest of Canadian society. For live-in caregivers, the workplace is a family home. For agricultural workers, the workplace is a 'family farm' - in public discourse if not in reality (Dunmore; Fudge, "Reply"). This combination of a lack of private life and the exclusion of their workplaces from the public sphere has implications for workers' transnational citizenship practices. The arguments of the Ontario government and the UFCW in Dunmore make this clear.

The Dunmore case grew out of changes to the Ontario provincial government during the 1990's. Agricultural labourers in Ontario had long been excluded from union membership in the province. When a New Democratic Party government was elected, it successfully tabled legislation to allow the formation of unions among farm workers. While the NDP government was in office, one group of workers obtained union certification, while others began the process (Dunmore). However, their efforts were thwarted when the Conservative party defeated the NDP in the following election. One of the Conservatives' first acts in government was to once again exclude agricultural workers from the right to unionize, decertifying any existing bargaining units in the process (Dunmore).

The exclusion of agricultural workers from the right to bargain collectively has a long history in Ontario and elsewhere in North America. It also marks yet another 
commonality between the work of live-in caregivers and that of agricultural workers today. According to Judy Fudge, an expert witness in Dunmore, the Ontario labour law which excluded farm workers from union membership was based on the 1935 National Labour Relations Act passed in the United States (Fudge). The 'Wagner Act,' as it is popularly known, protected U.S. workers from prosecution or firing in retaliation for union activities. Fudge cites 'administrative reasons' as the only official explanation given by the U.S. government for excluding farm workers from the protection of the Wagner Act. She goes on to state that "[s]ince this rationale was also used to explain the exclusion of domestic servants [...], it is likely that the family or household nature of the workplace was a main factor for the exclusion" (par. 13, emphasis added).

In the southern U.S. in 1935, "the majority of the farm workers were Black and at that time had little access to the political process" (Fudge, par. 15), while the white farmers' lobby was strong. Racism thus may also have had a significant role in the initial exclusion of agricultural workers from the right to unionize in the U.S. Farm workers and live-in caregivers continue to experience the effects of racialization in Canada today (Stasiulis and Bakan; Bauder and Corbin, 2002). In its submissions to the Supreme Court regarding discrimination against agricultural workers in Dunmore, the UFCW argued that:

[o]wing in part to the number of migrant workers, agricultural workers as a group are in large measure defined by and perceived to possess ascriptive characteristics associated with the enumerated grounds of race, national or ethnic origin and colour (UFCW, 2000: par. 29).

Meanwhile, in their empirical work on migrant caregivers in Canada, Stasiulis and Bakan (2005) explain in detail their findings that placement agencies involved in LCP recruitment engage in routine racist stereotyping of workers. "That is, the foreign 
domestic worker both in her home country and within Canada is subject to a specific series of ascriptive characteristics within a totalizing stereotype" (Stasiulis and Bakan: 77).

"[W]hatever the precise motivation for the exclusion of agricultural workers from employment protection legislation, its effect was clear: farm labourers, along with domestic servants, were relegated to the very lowest sector of the American socioeconomic scale" (Fudge, par. 15). As the Supreme Court observed in Dunmore, in 2001 "[t]he exclusionary section of the [Ontario Labour Relations Act] largely replicates the language of its predecessor [the pre-NDP legislation modelled on the Wagner Act]:

3. This Act does not apply,

(a) to a domestic employed in a private home;

(b) to a person employed in agriculture, hunting or trapping; [...]" (par. 100, emphasis in original).

The question raised in Dunmore reflects not only the social exclusion of agricultural workers, but that of domestic or caregiving workers as well. Today agricultural workers have only recently been included in Ontario health and safety coverage, while in Quebec LCP workers remain excluded from the worker's compensation regime (Quebec). Together, they have historically been left out of labour protections as a result of a combination of institutional racism and the designation of their work as properly within the private sphere of the home and family. In its factum for Dunmore, the Attorney General of Ontario relied heavily on the latter justification when arguing for the continued exclusion of agricultural workers from the right to unionize. An 
entire section of the written argument to the Supreme Court of Canada is devoted to "The Family Farm Structure of Ontario Agriculture" (AG Ontario, 14).

The Ontario government in Dunmore defined the 'family farm' as "a farm run as a family business, where most of the management, labour and capital is provided or supported (i.e. debt financing) by the family" (AG Ontario, 14). This definition fails to take into account the fact that there have been similar family businesses in Canada which were not farms, and to which the agricultural exclusion in the Ontario legislation would not apply in spite of family control over operations (Eaton, McCain and Bronfman come to mind). Moreover, as is shown below, the family farm is no longer representative of agribusiness in Ontario. Nevertheless, Ontario argued that $98.5 \%$ of farms in 2000 were family operated, most of which hired 10 or fewer workers (AG Ontario, 14).

In its written submissions the Ontario government went on to justify excluding agricultural workers from joining unions in a similar manner as that which Fudge states was used to justify the initial exclusion under the Wagner Act. In its view, there is too great a degree of integration between home and working life in Ontario agriculture for a collective bargaining regime to be appropriate. This integration is evidenced in both the relationships formed between people working on the farm and the use of space on the farm property:

These farms not only are family owned and operated, but also operate with a set of personal and informal relationships between home and business and between family members and supplementary workers that is unique in modern businesses. On family farms there typically is a strong integration of family and personal life with the farm business. The centre of this integration is the farm home, which typically is located on the business property and serves as a centre of both business activity and social interaction (AG Ontario, 14). 
The integration of work and family life is not limited to the farm family itself, but is said to extend to the hired workers, including (we can assume - though they are not parties in Dunmore) workers hired through the SAWP:

On many farms, housing is provided in the farmstead or on farm property for at least some of the permanent as well as seasonal employees. Farm children often spend time with hired help and their families. [...] The farm office is usually located within the family home, and the kitchen table often serves as the board room, briefing room, and contact location with workers. [...] Meals also may be shared, particularly during intensive work periods, where it is not uncommon for the farm family to cook meals in their home and bring food out to workers. Finally, working relationships with these hired workers are open, personal, informal, and integrated with the farm family life (AG Ontario).

The employment relationship described in the factum of the Attorney General of Ontario is not based on an employment contract between two autonomous liberal individuals. It is instead an 'open, personal, informal' relationship between people who live, work, eat and play together. There are no employers in this cooperative picture. There are only 'farm families'. By casting farm workers as simply an extension of farm families, the Ontario government ascribes a relationship of intimacy between worker and employer in an effort to establish an exclusionary line between public (citizen) and private (non-citizen) spheres. In the process, it seeks to prevent agricultural workers, including migrant workers, from exercising full political citizenship through free association in unions.

A similar tactic can be observed within the relationships between LCP workers and their employers. Living in the employer's home, with the care of children and vulnerable adults as one's primary occupation, care workers are often subject to this blurring of the line between servant and 'just like family' status. As 'Aline,' a caregiver 
working in Quebec remarks, an important part of protecting oneself is reminding the employer of the true basis of the relationship, difficult as this may be:

At the beginning, they used to tell me often that I was part of the family. It's true in a way, because I'm working in the family, but I'm not one of them. I say that so that it will be clear that I am doing a job, that I am a professional. I'm not an aunt who's there to help out. No. I am doing a job; in spite of that, however, I share the family's problems with them (Association des aides familiales du Québec)

In opposition to the enforced closeness of the family home, caregivers may adopt subtle tactics designed to put an artificial distance between employers and themselves. Advising the public about how she has managed to avoid being abused or 'propositioned' by her employers over the years, 'Ginette' (not an LCP participant) describes one such tactic:

You have to behave in such a way that a clear line is drawn. Yes, you're their employee. [...] But you have to put up a barrier between yourself and them, and they have to respect it. You always call them "vous" instead of "tu." You call the man "Monsieur," and the lady "Madame." It creates a distance that allows you to keep your own territory, even if you have to sleep on a folding bed in the dining room (Association des aides familiales du Québec).

Like the workers represented in Dunmore, many live-in caregivers understand the importance of association and organization for the improvement of their working and living conditions in Canada. Several organizations have initiated campaigns to change the legislation which affects care workers enrolled in the LCP (Stasiulis and Bakan; Association des aides familiales du Québec). The LCP itself was the result of concerted lobbying efforts by migrant caregivers concerned about abuses under the program's predecessor, the Foreign Domestic Workers Movement (FDM) (Status of Women Canada). Progress in these areas requires social recognition of the fact that the work that caregivers do may be a labour of love, but it is nevertheless a job. A live-in caregiver is at work when she is in her employer's home, just as a farm worker is at work when on the 
'family farm.' Worker strategies which directly engage the division between public and private as created by employers and the state, can successfully change public, judicial and legislative opinion.

The UFCW opposed the Ontario government's family-focused arguments by pointing out statistical information about the decline of family-run small farms in Ontario over the years (UFCW, 2000). The union explained to the court that, rather than being hired one by one to help a family in need of extra farm labour, hired agricultural workers were "becoming concentrated on fewer, larger corporate farms" (UFCW, 2000: par. 29). The UFCW pointed out that out of all Canadian provinces, only Alberta and Ontario continued to prevent agricultural workers from joining unions. In the past, through its denial of bargaining rights to farm workers, "Canadian society has systematically marginalized agricultural workers and in so doing has precluded them from becoming real citizens - individuals capable of participating fully in the country's political, economic and social life" (UFCW, 2000: par. 3).

Finding in favour of the appellants in Dunmore, the Supreme Court sided with the union's more industrial, corporate vision of present-day agriculture, rather than the family farm image promoted by the Attorney General of Ontario in the case. The redefinition of the family farm as an industrial workplace forced the Ontario government to change its law to permit the freedom of association of farm workers. In its analysis of the role of unions as labour associations, the court also remarked that unions are relevant not only for the sake of collective bargaining, but because they enable workers to do things collectively that they could not do on their own. 
What happened after Dunmore in the Ontario Legislature is an important lesson in the limits of the power of the courts to effect change under the Charter and similar instruments. Adopting a restrictive interpretation of the ruling in Dunmore, the Ontario government has since passed legislation allowing agricultural workers to form associations and to make collective representations to their employers. However, farm workers in Ontario are still not allowed the right most commonly gained through union membership: the right to bargain collectively for better pay and working conditions (Fraser v. Ontario). The UFCW is once again in court opposing the Ontario government for failing to meet the requirements of the Supreme Court judgment in Dunmore. As Fraser v. Ontario was only brought in 2005 , it may take years for the matter to be resolved for a second time.

Reaction to the new legislation among union spokespeople is understandably disappointed. One could argue that a union is of no use to the workers if it cannot bargain on their behalf and form a collective agreement with the employer. The main reason for most North-American workers for joining unions is the strength in numbers and bargaining power one gains when one does not have to stand alone in negotiations. That said, I would suggest that we apply the same conclusion to our understanding of the aftermath of Dunmore as we did in the example of parental leave benefits, above. The Ontario government reaction to Dunmore falls short of according full union membership rights to agricultural workers and as such continues the discrimination which workers in the industry have historically experienced. At the same time, we should not lose sight of the very different meanings that union membership or even a watered-down form of employee association may have for those agricultural 
workers who are migrants. As indicated by the gains made by caregivers' associations in minimum wage protection and other legislative changes, unions and other institutional allies can play a significant role in the struggles of workers who are enrolled in the SAWP. Membership in an employee association, however limited its objectives, should not be completely discounted - although full bargaining rights are a more just conclusion. The significance of a right to associate publicly and politically may be different for migrant workers than for those who enjoy the privilege of Canadian state citizenship.

The UFCW, as well as organizations which support live-in caregivers (INTERCEDE, the Immigrant Workers Centre and others) understand the importance of creating migrant worker support centres (Fraser v. Canada; Stasiulis and Bakan). In these locations not only can workers receive valuable information on their rights at work, but there is the possibility for developing social networks beyond the workplace. Both the creation of migrant support associations and the attainment of parental leave benefits help to create spaces of private life and interdependence where there are supposed to be none. These two strategies and outcomes are a beginning point in an discussion on how the creation of a private sphere of life by migrating workers, for themselves, can help to develop their citizenship in the public sense as well.

\section{Conclusion}

In writing this thesis, I chose to focus on the Seasonal Agricultural Workers Program and the Live-In Caregiver program as examples of migrant work in Canada. I did so because their comparison enables a gendered understanding of transnational citizenship which highlights potential strategies for legal change among workers and their allies. Both live-in caregiving work and agricultural work have historically been seen as 
the work of marginalized people. Care work has traditionally been considered 'women's work,' performed by second-class citizens who were underpaid and had little access to the Canadian political sphere. In the case of farm labour, a masculinized occupation in Canada, the state has historically sought to remedy labour shortages with easily-coerced groups such as detainees, displaced persons and individuals receiving social assistance. Through the adoption of labour relations schemes based on the U.S. Wagner Act, care workers and farm labourers have been historically denied full citizenship in Canadian society. This denial extends into the present day, where workers in both industries continue to be excluded from certain labour standards which apply to other employees in Canada.

Migrants working in the above industries are even more vulnerable to coercion, as their ability to live and work in Canada is dependent on a permit system which binds them to a single employer and limits their labour mobility once in Canada. Nevertheless, this same system recognizes migrants' ability to exercise the civil right of freedom of contract by signing on to work for Canadian employers. The motivations of workers to enter Canada are complex, however they can be linked to economic policies of their home states which conform to the expectations of powerful international lending institutions and wealthy trading partners, as in the case of Mexico and the NAFTA. The remittances of migrant workers are a much-needed source of foreign currency in their countries of origin, outweighing foreign direct investment from wealthier states. Through the remittances workers send to their families, the public economic well-being of entire states is encouraged by the private relationships between workers and their close 
relatives. In this sense, migrant workers are transnational citizens from the moment they engage with an employer to work in Canada.

Once in Canada however, workers' citizenship is limited not only by their juridical status as non-citizens, but through a series of manipulations of the public-private distinction and the denial of relations of interdependence between migrants, their families and the broader Canadian society. Through the migrant selection process, and subsequent social isolation in Canada, workers are discouraged from forming lasting personal relationships with Canadian citizens. They are unable to bring family members with them to Canada while on a work term, and thus are 'free' to work unhindered by distractions beyond their relatives' need for a steady income. At the same time as workers are discouraged from forming a private life in Canada, their workplaces are defined as being outside the public (political) sphere. In the case of caregivers, their place of work is a family home. SAWP participants work on 'family farms'.

Debates over the definition of a workplace as belonging to the public or private sphere, and over the recognition of personal relationships, are points of possible resistance for migrant workers and their allies. This is shown in the cases studied in Chapter Four, in which migrant workers and their allies applied in the courts for their interpretations to be upheld. Rather than simply ending in a rhetorical exercise, the cases of Fraser v. Canada and Dunmore have resulted in concrete financial gains and state recognition for migrant workers living in Canada. They demonstrate that the shared experiences of migrant caregivers and agricultural workers as marginalized transnational citizens are not inevitable. On the contrary, they may be subject to change in the future. 


\section{Bibliography}

Anderson, Bridget. Doing the Dirty Work? the Global Politics of Domestic Labour. London and New York: Zed Books, 2000.

---. "Why Madam has so Many Bathrobes?: Demand for Migrant Workers in the EU." Tijdschrift voor Economische en Sociale Geographie 92.1 (2001): 18.

Artner, Annamaria. "Anti-Globalization Movements: The Developments in Asia." Contemporary Politics 10.3-4 (2004): 243-55.

Asis, Maruja Milagros B., Shirlena Huang, and Brenda S. A. Yeoh. "When the Light of the Home is Abroad: Unskilled Female Migration and the Filipino Family." Singapore Journal of Tropical Geography 25.2 (2004): 198.

Association des aides familiales de Montréal. "Beyond the Call of Duty." Montreal Historical Centre (2001) $<$ http://www2.ville.montreal.qc.ca/chm/aides/parfaitesa.htm $>$.

Attorney General of Ontario. Factum of the Respondent, Dunmore v. A-G Ontario. 2000.

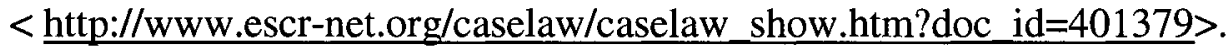

Backhouse, Constance. Colour Coded: A Legal History of Racism in Canada, 1900-1950. Toronto: University of Toronto Press, Osgoode Society for Canadian Legal History, 1999.

Baines, Donna, and Nandita Sharma. "Migrant Workers as Non-Citizens: The Case Against Citizenship as a Social Policy Concept." Studies in Political Economy 69 (2002): 75-107.

Basok, Tanya. "Post-National Citizenship, Social Exclusion and Migrants Rights." Citizenship Studies 8.1 (2004): 47-64.

---. Tortillas and Tomatoes: Transmigrant Mexican Harvesters in Canada. Montreal: McGill-Queen's University Press, 2002.

Bauder, Harald, and Margot Corbin. Foreign Farm Workers in Ontario: Representations in the Newsprint Media. University of Guelph, 2002.

Benoit, Leon E. Edited Hansard Number 94, 36th Parliament, 2nd Session, Wednesday May $10,2000$.

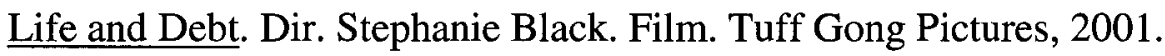


Blackett, Adelle. "Making Domestic Work Visible: The case for specific regulation." Labour Law and Labour Relations Programme Working Paper No. 2. Geneva: International Labour Organization, 1998. <http://www.ilo.org/public/english/dialogue/govlab/papers/1998/domestic/>.

Canadian Heritage. "Answers to Specific Questions.” 27/11/03. $<$ http://www.pch.gc.ca/progs/pdp-hrp/docs/questionnaire/question07 e.cfm $>$.

Citizenship and Immigration Canada. "Foreign Worker Overview." Monitor 2006.

---. "The Live-In Caregiver Program for employers and caregivers abroad." Citizenship and Immigration Canada. Nov. 212002. $<$ http://www.cic.gc.ca/english/pub/caregiver/index.html $>$.

---. "Processing Live-In Caregivers in Canada." Chapter 4 in Inland Processing (Policy and Program Manual). Citizenship and Immigration Canada. 2005. $<$ http://www.cic.gc.ca/manuals-guides/english/ip/ip04e.pdf $>$

December 18.net. 'UN Migrant Workers' Convention Country Positions.” December 18.net. 22/03/07.

$<$ http://www.december18.net/web/general/page.php?pageID=84\&menuID=36\&lang $=\mathrm{EN}>$.

Familiar, Jorge. Second International Conference on Migrant Remittances, London, November 13-14, 2006: Remarks of Jorge Familiar, Executive Director, World Bank. World Bank, 2006.

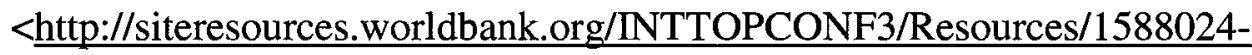
1163704792404/S1 P1 FAMILIAR.doc>.

FARMS. "FARMS Ontario." 22/03/07. <www.farmsontario.ca>.

Fineman, Martha A. The Autonomy Myth: A Theory of Dependency. New York: The New Press, 2004.

Fineman, Martha L. A. "Masking Dependency: The Political Role of Family Rhetoric." The Subject of Care: Feminist Perspectives on Dependency. Ed. Eva Feder Kittay and Ellen K. Feder. Boston: Rowman and Littlefield, 2002. 215-244.

Fox, Jonathan. “Unpacking 'Transnational Citizenship'.” Annual Review of Political Science 8 (2005): 171-201.

Fraser, Nancy. "After the Family Wage: A Postindustrial Thought Experiment." Justice Interruptus. New York: Routledge, 1997. 41-66. 
---. "After the Family Wage: Gender Equity and the Welfare State." Political Theory 22.4 (1994): 591-618.

Fudge, Judy. “Affidavit of Judy Fudge (First).” Toronto, 1997. <http://www.escrnet.org/caselaw/caselaw show.htm?doc_id=401379>.

---. “Affidavit of Judy Fudge (Reply)." Toronto, 1997. < http://www.escrnet.org/caselaw/caselaw show.htm?doc id=401379>.

Gavison, Ruth. "Feminism and the Public/Private Distinction." Stanford Law Review 45.1 (1992): 1-45.

Grez, Evelyn Encalada. "Harvesting Seeds of Justice: The Plight of Migrant Farm Workers in Ontario." Women and Environments International Magazine 68/69 (2005). $<$ www.december18.net $>$.

Gutierrez, Israel Gonzalez. Protection of Migrant Agricultural Workers' Rights. MA Department of Social Work, McMaster University, 2006 Hamilton, Ontario. $<$ www.justicia4migrantworkers.org $>$.

Hall, Stuart, and David Held. "Citizens and Citizenship." New Times. the Changing Face of Politics in the 1990s. Ed. Stuart Hall and M. Jacques. London: Lawrence and Wishart.

Hardt, Michel, and Antonio Negri. Empire. Cambridge: Harvard University Press, 2000.

Heckscher, Zahara. "Long before Seattle: Historical Resistance to Economic Globalization." Global Backlash: Citizen Initiatives for a just World Economy Ed. Robin Broad. Lanham, MD: Rowman and Littlefield, 2002. 86-91.

Ibbetson, David J. A Historical Introduction to the Law of Obligations. New York: Oxford University Press, 1999.

Justicia for Migrant Workers. "Justicia for Migrant Workers." 02/20/07. $<$ www.justicia4migrantworkers.org $>$.

El Contrato. Dir. Min Sook Lee. Film. National Film Board of Canada, 2003.

Lewis, Stephen. Race Against Time: Searching for Hope in AIDS-Ravaged Africa. 2nd ed. Toronto: House of Anansi Press, 2005.

Lowry, Edith E. Migrants of the Crops: they starve that we may eat. New York: Council of Women for Home Missions and Mission Education Movement, 1938. 
Marshall, T. H. "Citizenship and Social Class." Sociology at the Crossroads and Other Essays. London: Heinemann, 1963.

McQueen, Alison. Canadian Hegemony in the Continental Periphery: An Analysis of the Role of the Canadian State in the Seasonal Agricultural Workers Program. York University, Toronto: Presentation for the Canadian Political Science Association Conference, 2006.

Montgomery, Sue. "Abortion becomes price of a job. Pregnant nanny is fired." Montreal Gazette. March 302003.

<http://www.muslimcouncil.org/en/2003/04/call the montreal gazette and.html $>$.

Ontario Ministry of Labour, and Ontario Ministry of Agriculture and Food.

"Backgrounder: Improving Occupational Health and Safety on Farms." Ontario Ministry of Labour. June 20, 20062006.

<http://www.labour.gov.on.ca/english/news/2006/06-73b.html>.

Organization for Economic Cooperation and Development (OECD). OECD Employment Outlook 2004: How does Mexico Compare?., 2003.

Preibisch, Kerry. Social Relations Practices between Seasonal Agricultural Workers, their Employers, and the Residents of Rural Ontario. Ottawa, Ontario: North-South of Institute, 2003.

Privy Council Office. "Joint Statement by Canada and Mexico: A commitment to our common future." Ottawa, Ontario. October 25 2004. <http://www.pcobcp.gc.ca/default.asp?Language $=E \& P a g e=$ archivemartin $\&$ Sub $=$ newscommuniques \&Doc=news release 20041025296 e.htm>

Richmon, Randy. "The Killing Fields: A Migrant worker's Sad End on an Ontario Tobacco Farm." London Free Press November 162004. <www.justicia4migrantworkers.org $>$.

Rodriguez, Robyn M. "Migrant Heroes: Nationalism, Citizenship and the Politics of Filipino Migrant Labor." Citizenship Studies 6.3 (2002): 341-56.

Satzewich, Vic. Racism and the Incorporation of Foreign Labour: Farm Labour Migration to Canada since 1945. London: Routledge, 1991.

Sharma, Nandita. Home Economics: Nationalism and the Making of 'Migrant Workers' in Canada. Toronto: University of Toronto Press, 2006. 
Sparke, Matthew. "Passports into Credit Cards: On the Borders and Spaces of Neoliberal Citizenship." Boundaries and Belonging: States and Societies in the Struggle to Shape Identities and Local Practices. Ed. Joel S. Migdal. Cambridge: Cambridge University Press, 2004.

Stasiulis, Daiva K., and Abigail Bakan. Negotiating Citizenship: Migrant Women in Canada and the Global System. Toronto: University of Toronto Press, 2005.

Status of Women Canada. Trafficking in Women in Canada: A Critical Analysis of the Legal Framework Governing Immigrant Live-in Caregivers and Mail-Order Brides. Status of Women Canada, 2003. Feb. $212007<$ http://www.swccfc.gc.ca/pubs/pubspr/066231252X/200010 066231252X 2 e.html >.

United Food and Commercial Workers Canada. UFCW Canada National Report on the Status of Migrant Farm Workers in Canada, 2004. United Food and Commercial Workers Canada, 2004.

--- . Factum of the Appellant, Dunmore v. A-G Ontario. $2000 .<$ http://www.escrnet.org/caselaw/caselaw show.htm?doc id=401379>.

Velasco, Pura. "Filipino Migrant Workers Amidst Globalization." Canadian Woman Studies Spring/Summer 2002: 131.

Verma, Veena. The Caribbean and Mexican Seasonal Agricultural Workers Program Institutional Framework: Labour Policies, Regulations, Farm Industry Level Employment Practices, and the Future of the Program Under Unionization. Ottawa, Ontario: Report to the North-South Institute, 2003.

White, Marceline, Carlos Salas, and Sarah Gammage. NAFTA and the FTAA: A Gender Analysis of Employment and Poverty Impacts in Agriculture. Womens Edge Coalition, 2003. $<$ http://www.womensedge.org/documents/mexicocasestudyfinal.pdf $>$.

Wodon, Quentin, et al. "Migration and Poverty in Mexico's Southern States." Development Strategy for the Mexican Southern States Ed. World Bank.World Bank, 2003. 13. <http://wbln0018.worldbank.org/LAC/lacinfoclient.nsf/d29684951174975c8525673 5007fef12/63a3f4e71ce14d2385256dc500661aaf/\$FILE/Mexico\%20SouthStates\%2 OMigration.pdf $>$.

World Bank. Global Economic Prospects: Overview and Global Outlook. Washington: World Bank, 2006. <http://siteresources.worldbank.org/INTGEP2006/Resources/summary.pdf>. 
---. Remittance Data., 2006.

<http://econ.worldbank.org/WBSITE/EXTERNAL/EXTDEC/EXTDECPROSPECT S/GEPEXT/EXTGEP2006/0,contentMDK:20792338 menuPK:2138997 pagePK:6 4167689 piPK:64167673 theSitePK:1026804,00.html>.

\section{Legislation}

Government of Quebec. Act Respecting Industrial Accidents and Occupational Diseases, R.S.Q. c. A-3.001.

Government of Quebec. Act Respecting Labour Standards, R.S.Q. ch. N-1.1.

Government of Canada. Citizenship Act, R.S. 1985 c. C-29.

Government of Canada. Employment Insurance Act, 1996, c. 23.

Government of Canada. Immigration and Refugee Protection Act, 2001, c. 27.

United Nations Organization. International Convention on the Protection of the Rights of all Migrant Workers andMembers of their Families (Convention). Trans. Officer of the High Commissioner for Human Rights.

\section{Cases}

Baker v. Canada (Minister of Citizenship and Immigration). Supreme Court of Canada, 1999.

Baker v. Canada (Minister of Citizenship and Immigration). Federal Court of Canada, Trial Division, 1995.

Dunmore v. Ontario (Attorney General). Supreme Court of Canada, 2001.

Fraser v. Canada (Attorney General). Ontario Superior Court of Justice, 2005.

Fraser v. Ontario (Attorney General). Ontario Superior Court of Justice, 2006.

Lavigne v. Ontario Public Service Employees Union. Supreme Court of Canada, 1991. 